SUPPORTING INFORMATION

\title{
Ozone-induced DNA damage: A pandora box of oxidatively modified DNA bases
}

\author{
J. Richard Wagner, Guru S. Madugundu and Jean Cadet
}




\section{CONTENTS}

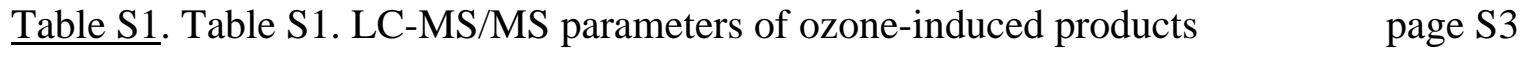

Figure S1. Digestion of single oxidation products by C-18 chromatography page S4-S5

Figure S2. Digestion of single oxidation products by Hypercarb chromatography page S6-S7

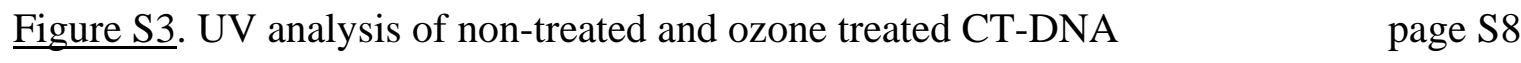

Figure S4. Digestion of dinucleotide products containing fragments page S9-S10

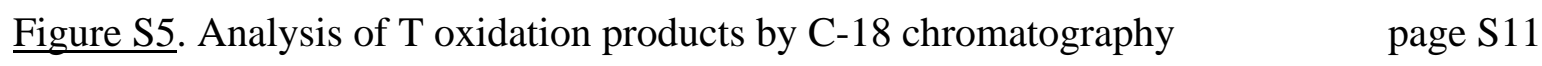

Figure S6. Analysis of T oxidation products by Hypercarb chromatography page S11

Figure S7. Analysis of C oxidation products by C-18 chromatography page S12

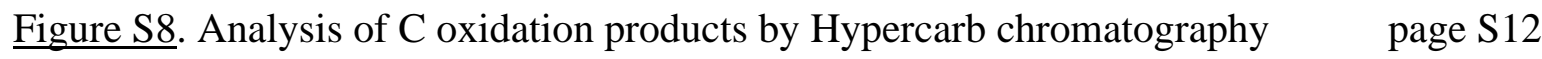

Figure S9. Analysis of $5 \mathrm{mC}$ oxidation products by $\mathrm{C}-18$ chromatography page S13

Figure S10. Analysis of $5 \mathrm{mC}$ oxidation products by Hypercarb chromatography page S13

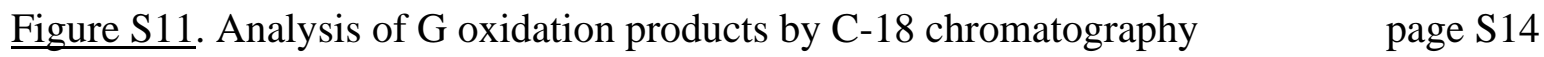

Figure S12. Analysis of G oxidation products by Hypercarb chromatography page S14

Figure S13. Formation of C oxidation products $\quad$ page S15

Figure S14. Formation of 5mC oxidation products $\quad$ page S16

Figure S15. Formation of G oxidation products $\quad$ page S17

Figure S16. LC-MS/MS analysis of N-formamide products $\quad$ page S18

Figure S17. Formation of dinucleotides containing N-formamide fragments page S19

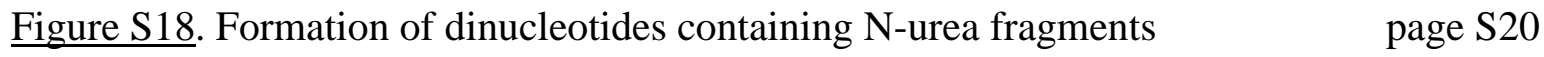

Figure S19. Formation of dinucleotides containing N,N-formylurea fragments page S21

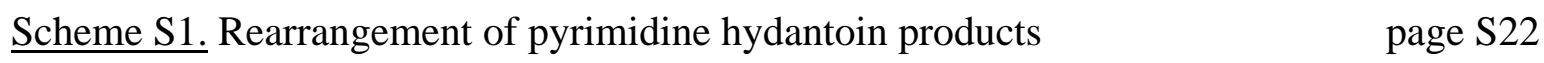

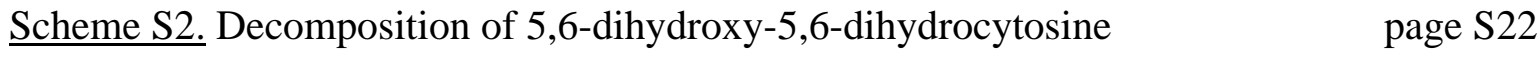


Table S1. LC-MS/MS parameters of single oxidation products and modified dinucleotides.

\begin{tabular}{|c|c|c|c|}
\hline Product & $\begin{array}{l}\text { Retention } \\
\text { time }\end{array}$ & MS/MS transition & \begin{tabular}{|l} 
Collision \\
Energy
\end{tabular} \\
\hline \multicolumn{4}{|c|}{ Single oxidation products } \\
\hline T-Hyd & $(11.4+12.1)^{\mathrm{b}}$ & $264\left(\mathrm{MNH}_{4}{ }^{+}\right) \rightarrow 117\left(\mathrm{dRH}^{+}\right)^{\mathrm{e}}$ & +20 \\
\hline T-Gly & $(11.3+11.5)^{\mathrm{b}}$ & $294\left(\mathrm{MNH}_{4}{ }^{+}\right) \rightarrow 117\left(\mathrm{dRH}^{+}\right)^{\mathrm{e}}$ & +25 \\
\hline $5 \mathrm{hmU}$ & $10.1^{\mathrm{a}}$ & $259\left(\mathrm{MH}^{+}\right) \rightarrow 125\left(\mathrm{BH}^{+}-\mathrm{H}_{2} \mathrm{O}\right)^{\mathrm{d}}$ & +15 \\
\hline $5 \mathrm{fU}$ & $12.7^{\mathrm{a}}$ & $257\left(\mathrm{MH}^{+}\right) \rightarrow 141\left(\mathrm{BH}^{+}\right)^{\mathrm{d}}$ & +15 \\
\hline U-Hyd & $12.1^{\mathrm{b}}$ & $250\left(\mathrm{MNH}_{4}{ }^{+}\right) \rightarrow 117\left(\mathrm{dRH}^{+}\right)^{\mathrm{e}}$ & +20 \\
\hline U-Gly & $(12.2+12.3)^{\mathrm{b}}$ & $280\left(\mathrm{MNH}_{4}{ }^{+}\right) \rightarrow 117\left(\mathrm{dRH}^{+}\right)^{\mathrm{e}}$ & +19 \\
\hline $5 \mathrm{ohC}$ & $9.3^{\mathrm{a}}$ & $244\left(\mathrm{MH}^{+}\right) \rightarrow 128\left(\mathrm{BH}^{+}\right)^{\mathrm{d}}$ & +15 \\
\hline C-Imid & $12.5^{\mathrm{b}}$ & $278\left(\mathrm{MH}^{+}\right) \rightarrow 260\left(\mathrm{MH}^{+}-\mathrm{H}_{2} \mathrm{O}\right)^{\mathrm{d}}$ & +8 \\
\hline $5 \mathrm{mC}-\mathrm{Hyd}$ & $(9.5+10.4)^{b}$ & $246\left(\mathrm{MH}^{+}\right) \rightarrow 130\left(\mathrm{BH}^{+}\right)^{\mathrm{d}}$ & +16 \\
\hline 5mC-Gly & $9.1^{\mathrm{b}}$ & $276\left(\mathrm{MH}^{+}\right) \rightarrow 117\left(\mathrm{dRH}^{+}\right)^{\mathrm{d}}$ & +24 \\
\hline $5 \mathrm{hmC}$ & $9.5^{\mathrm{a}}$ & $258\left(\mathrm{MH}^{+}\right) \rightarrow 142\left(\mathrm{BH}^{+}\right)^{\mathrm{d}}$ & +15 \\
\hline $5 \mathrm{fC}$ & $13.4^{\mathrm{a}}$ & $256\left(\mathrm{MH}^{+}\right) \rightarrow 140\left(\mathrm{BH}^{+}\right)^{\mathrm{d}}$ & +15 \\
\hline $80 \times 0 G$ & $13.6^{\mathrm{a}}$ & $284\left(\mathrm{MH}^{+}\right) \rightarrow 168\left(\mathrm{BH}^{+}\right)^{\mathrm{d}}$ & +15 \\
\hline $\mathrm{Sp}$ & $(17.2+18.8)^{\mathrm{b}}$ & $300\left(\mathrm{MH}^{+}\right) \rightarrow 117\left(\mathrm{BH}^{+}\right)^{\mathrm{d}}$ & +18 \\
\hline Gh & $8.0^{\mathrm{b}}$ & $274\left(\mathrm{MH}^{+}\right) \rightarrow 117\left(\mathrm{BH}^{+}\right)^{\mathrm{d}}$ & +23 \\
\hline \multicolumn{4}{|c|}{ Modified dinucleotides } \\
\hline $\mathrm{P}^{\mathrm{F}} \mathrm{pA}$ & $7.8^{\mathrm{a}} ; 9.6^{\mathrm{c}}$ & $473\left(\mathrm{M}-\mathrm{H}^{-}\right) \rightarrow 330\left(\mathrm{pA}-\mathrm{H}^{-}\right)^{\mathrm{f}}$ & -30 \\
\hline $\mathrm{P}_{\mathrm{F}}^{\mathrm{F} G}$ & $7.7^{\mathrm{a}} ; 8.8^{\mathrm{c}}$ & $489 n\left(\mathrm{M}-\mathrm{H}^{-}\right) \rightarrow 346\left(\mathrm{pG}-\mathrm{H}^{-}\right)^{\mathrm{f}}$ & -30 \\
\hline $\mathrm{P}^{\mathrm{F}} \mathrm{pC}$ & $6.2^{\mathrm{a}} ; 8.6^{\mathrm{c}}$ & $449\left(\mathrm{M}-\mathrm{H}^{-}\right) \rightarrow 306\left(\mathrm{pC}-\mathrm{H}^{-}\right)^{\mathrm{f}}$ & -40 \\
\hline $\mathrm{P}^{\mathrm{F}} \mathrm{pT}$ & $7.7^{\mathrm{a}} ; 8.9^{\mathrm{c}}$ & 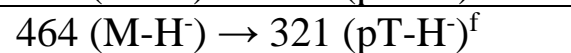 & -30 \\
\hline $\mathrm{P}^{\mathrm{F}} \mathrm{p} 8$ oxoG & $9.3^{\mathrm{c}}$ & $505\left(\mathrm{M}-\mathrm{H}^{-}\right) \rightarrow 362\left(\mathrm{p} 8 \mathrm{oxoG}-\mathrm{H}^{-}\right)^{\mathrm{f}}$ & -30 \\
\hline $\mathrm{P}^{\mathrm{U}} \mathrm{pA}$ & $9.5^{\mathrm{c}}$ & $488\left(\mathrm{M}-\mathrm{H}^{-}\right) \rightarrow 330\left(\mathrm{pA}-\mathrm{H}^{-}\right)^{\mathrm{f}}$ & -35 \\
\hline $\mathrm{P}_{\mathrm{pG}}^{\mathrm{U}}$ & $7.7^{\mathrm{a}} ; 8.8^{\mathrm{c}}$ & $504\left(\mathrm{M}-\mathrm{H}^{-}\right) \rightarrow 346\left(\mathrm{pG}-\mathrm{H}^{-}\right)^{\mathrm{f}}$ & -35 \\
\hline $\mathrm{P}_{\mathrm{pC}}^{\mathrm{U}}$ & $6.5^{\mathrm{a}} ; 8.6^{\mathrm{c}}$ & 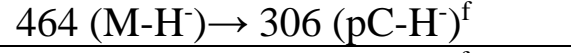 & -35 \\
\hline $\mathrm{P}^{\mathrm{U}} \mathrm{pT}$ & $8.8^{\mathrm{c}}$ & $479\left(\mathrm{M}-\mathrm{H}^{-}\right) \rightarrow 321\left(\mathrm{pT}^{-} \mathrm{H}^{-}\right)^{\mathrm{f}}$ & -35 \\
\hline $\mathrm{P}^{\mathrm{U}} \mathrm{p} 8 \mathrm{oxoG}$ & $9.3^{\mathrm{c}}$ & $520\left(\mathrm{M}-\mathrm{H}^{-}\right) \rightarrow 362\left(\mathrm{p} 8 \mathrm{oxoG}-\mathrm{H}^{-}\right)^{\mathrm{f}}$ & -35 \\
\hline $\mathrm{P}^{\mathrm{FU}} \mathrm{pA}$ & $11.3^{\mathrm{c}}$ & $531\left(\mathrm{M}-\mathrm{H}^{-}\right) \rightarrow 330\left(\mathrm{pA}-\mathrm{H}^{-}\right)^{\mathrm{f}}$ & -35 \\
\hline $\mathrm{P}^{\mathrm{FU}} \mathrm{pG}$ & $7.7^{\mathrm{a}} ; 8.7^{\mathrm{c}}$ & $532\left(\mathrm{M}-\mathrm{H}^{-}\right) \rightarrow 346\left(\mathrm{pG}-\mathrm{H}^{-}\right)^{\mathrm{f}}$ & -35 \\
\hline $\mathrm{P}^{\mathrm{FU}} \mathrm{pC}$ & $8.7^{\mathrm{c}}$ & $492\left(\mathrm{M}-\mathrm{H}^{-}\right) \rightarrow 306\left(\mathrm{pC}-\mathrm{H}^{-}\right)^{\mathrm{f}}$ & -35 \\
\hline $\mathrm{P}^{\mathrm{FU}} \mathrm{pT}$ & $9.2^{\mathrm{c}}$ & $507\left(\mathrm{M}-\mathrm{H}^{-}\right) \rightarrow 321\left(\mathrm{pT}^{\left.-\mathrm{H}^{-}\right)^{\mathrm{f}}}\right.$ & -35 \\
\hline $\mathrm{P}^{\mathrm{FU}} \mathrm{p} 8 \mathrm{oxoG}$ & $9.8^{\mathrm{c}}$ & $563\left(\mathrm{M}-\mathrm{H}^{-}\right) \rightarrow 362\left(\mathrm{p} 80 \times \mathrm{oxoG}-\mathrm{H}^{-}\right)^{\mathrm{f}}$ & -35 \\
\hline
\end{tabular}

(a)Separation on a C-18 column as described in Materials and Methods; (b)Separation on a Hypercarb column as described in Materials and Methods; (c)Separation same as in (a) except the gradient started at 5\% ACN instead of $10 \% \mathrm{ACN}$; (d) Mass of $\mathrm{MH}^{+}(\mathrm{m} / z)$ in positive mode; (e)Mass $(\mathrm{m} / \mathrm{z})$ of $\mathrm{MNH}_{4}{ }^{+}$in positive mode; (f)Mass of M-H $(\mathrm{m} / \mathrm{z})$ in negative mode. Additional LC-MS/MS data: desolvation and nebulizer gas= dry zero air; curtain and CAD gas- $\mathrm{N}_{2}$; dwell time $=100 \mathrm{~ms}$; source temperature $=450^{\circ} \mathrm{C}$; and ionization setting $=4500$ in positive mode $(-4500$ in negative mode); and resolution $\mathrm{Q} 1=\mathrm{Q} 3=$ unit $(\mathrm{FWHM}=0.7 \mathrm{Da})$. 
Figure. S1
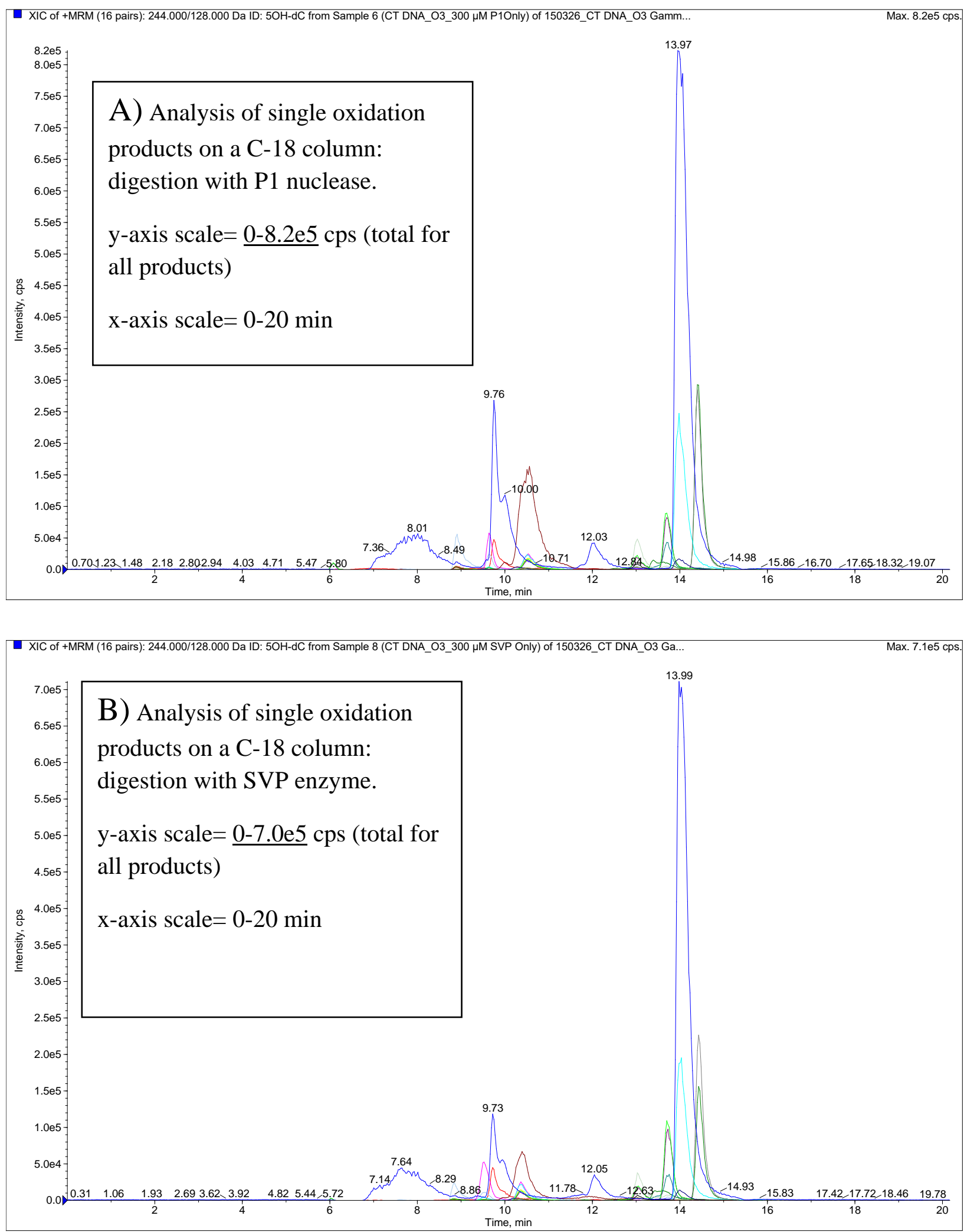
Figure S1. cont.

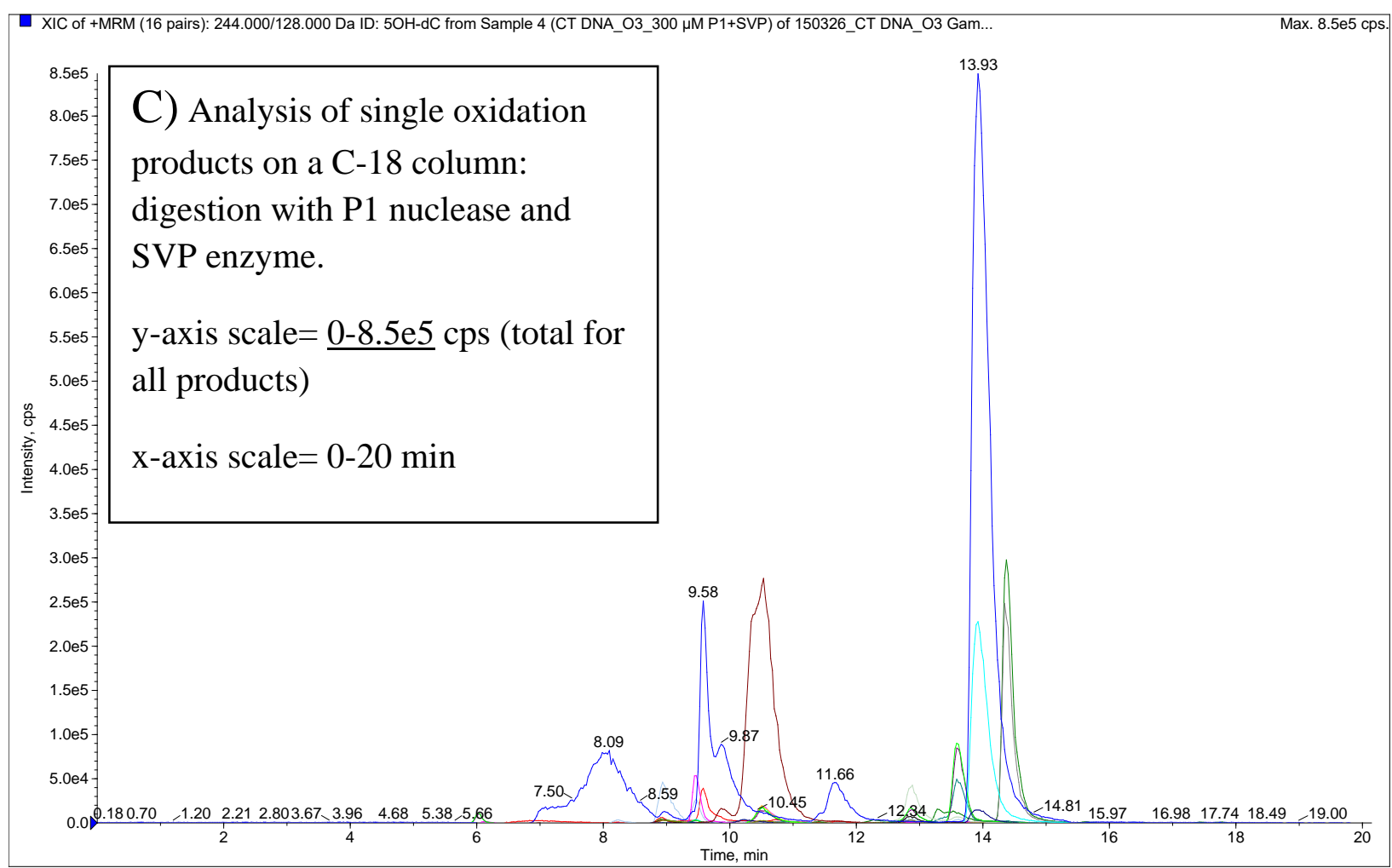

Figure S1. Analysis of single oxidation products by LC-MS/MS within CT-DNA treated with $300 \mu \mathrm{M}$ ozone and digested with different digestion protocols. A) digestion with P1 nuclease; B) digestion with SVP enzyme; C) digestion with P1 nuclease and SVP enzyme. Final digestion with alkaline phosphatase was included in all protocols. Y-axis represents total ion signal in counts per $\min (\mathrm{cps})$. The total ion counts include MS/MS signals for all products that were separated by C-18 chromatography: 5hmU, 5fU, 5ohC, 5hmC and $5 \mathrm{fC}$ and $80 x o G$. Note the different $y$-axis scale in each sample. 
Figure. S2

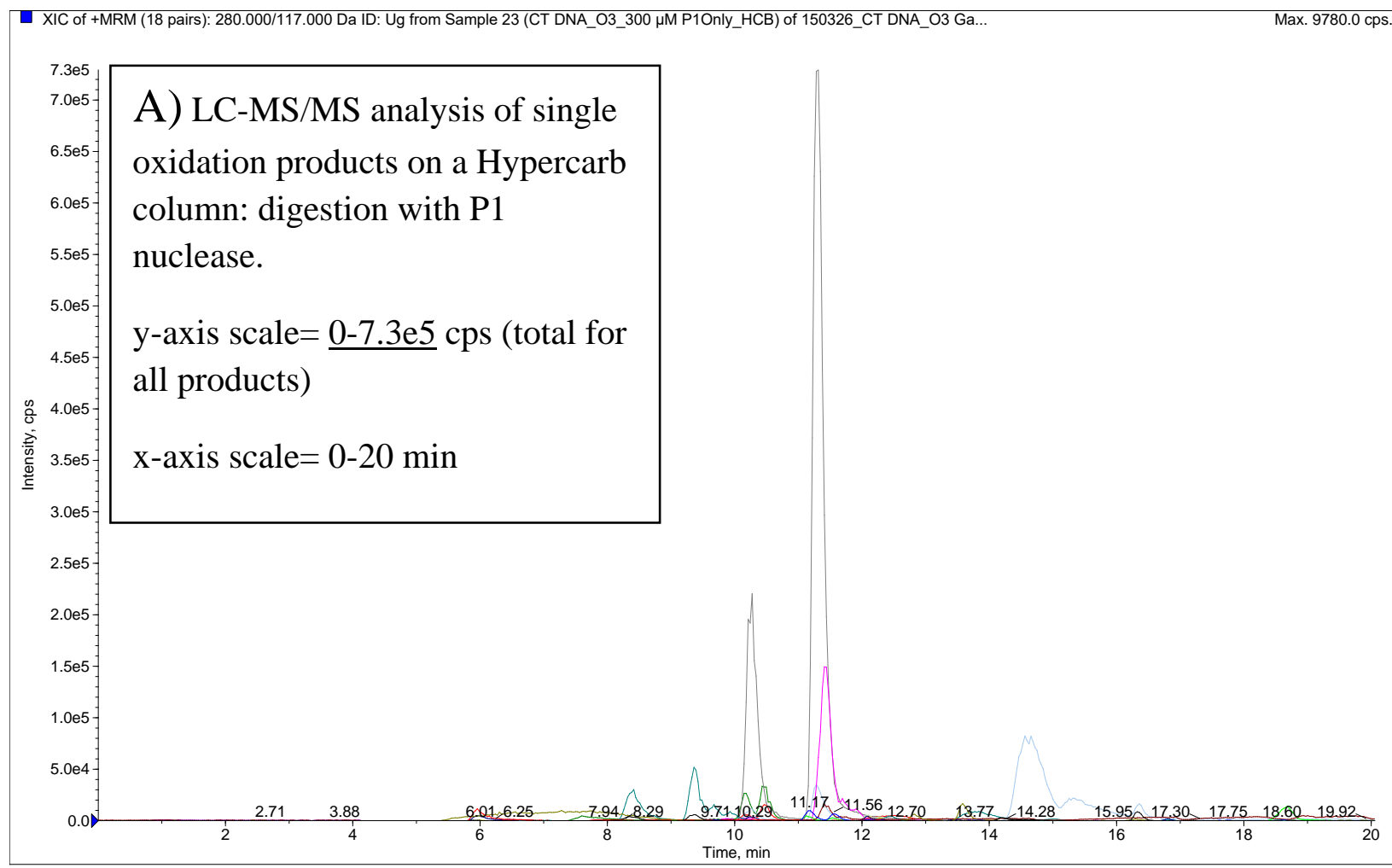

- XIC of +MRM (18 pairs): 280.000/117.000 Da ID: Ug from Sample 25 (CT DNA_O3_300 $\mu$ M SVP Only_HCB) of 150326_CT DNA_O3 G...

Max. $1.5 \mathrm{e} 4 \mathrm{cps}$

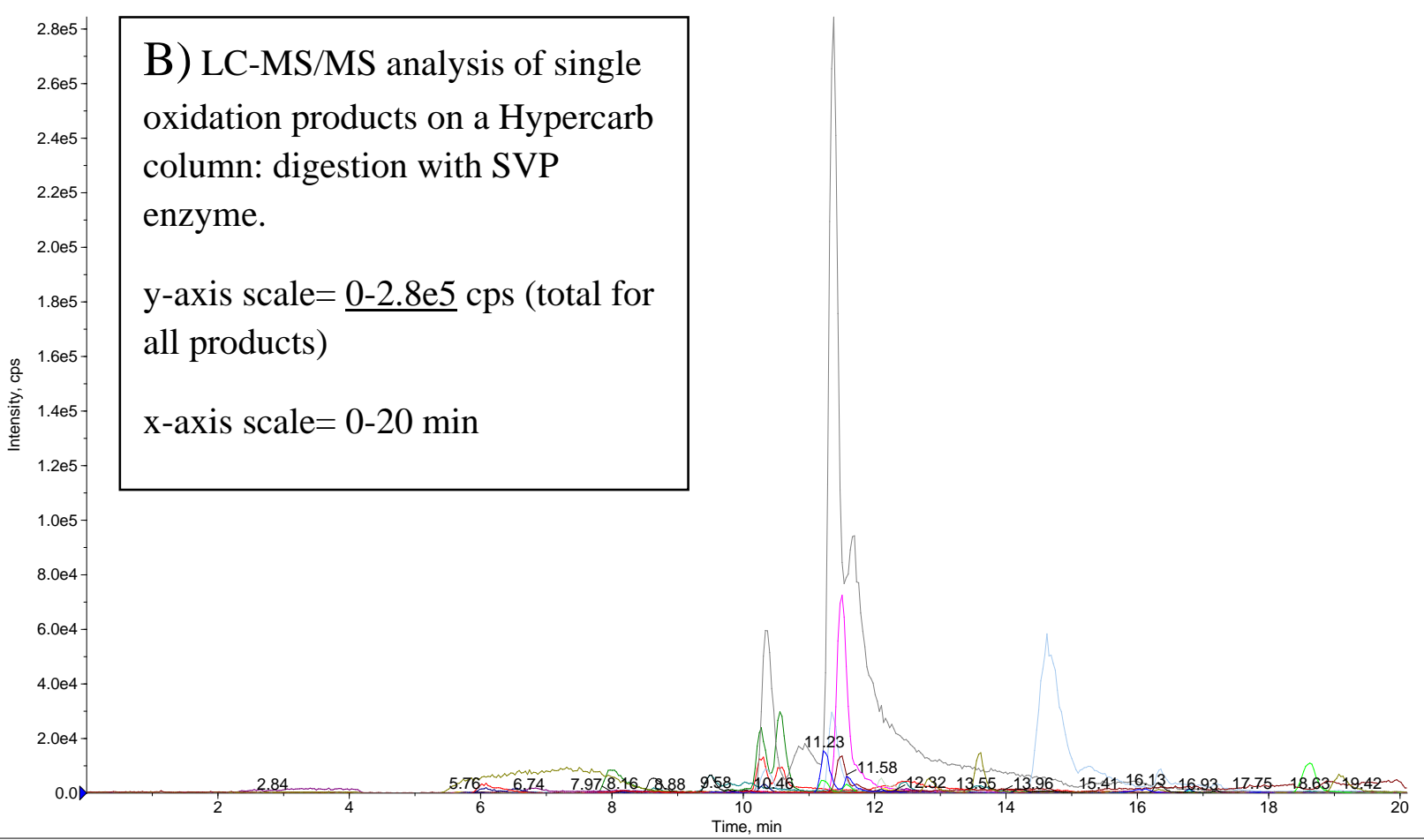


Figure S2. cont.

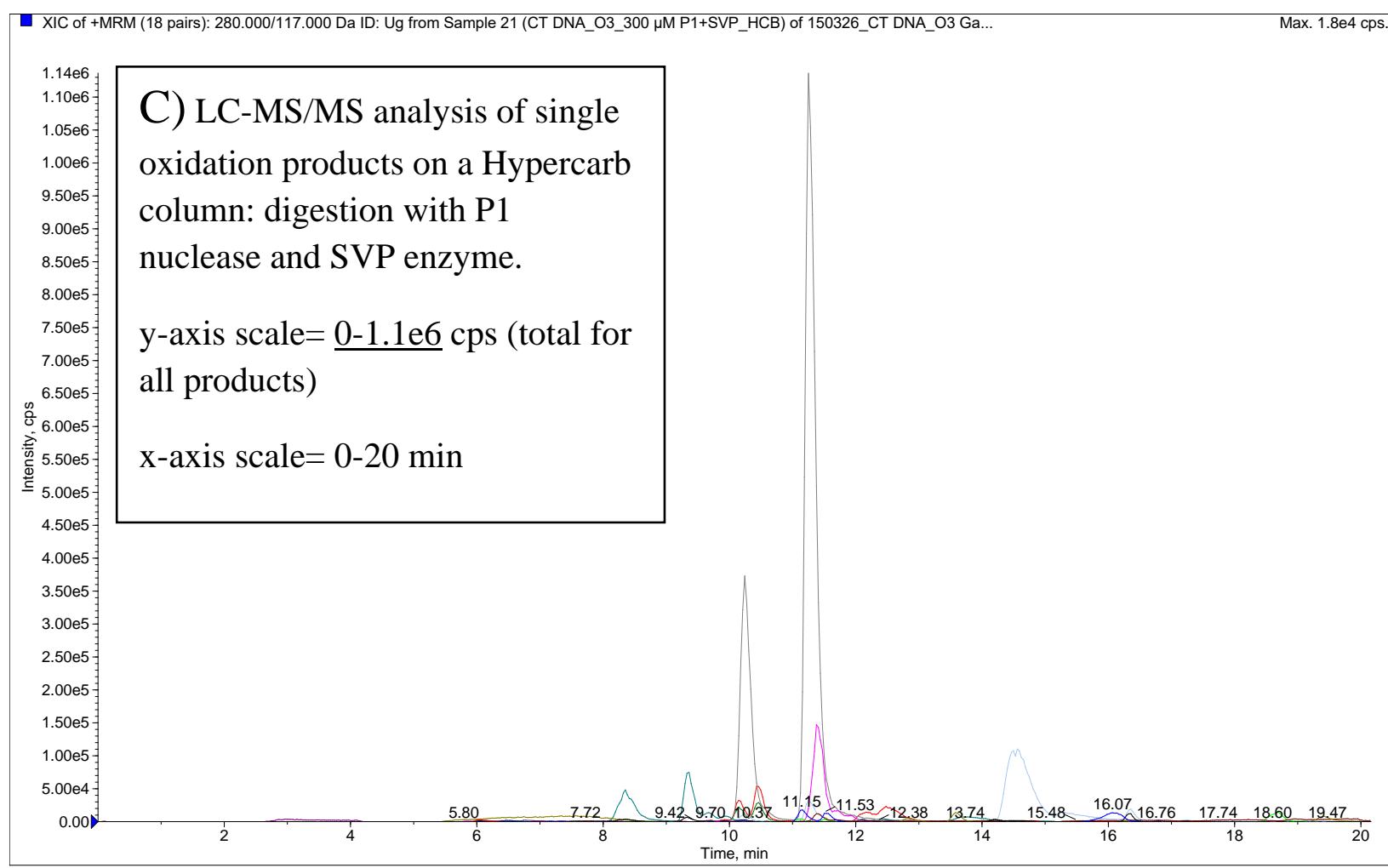

Figure S2. Analysis of single oxidation products by LC-MS/MS within CT-DNA treated with $300 \mu \mathrm{M}$ ozone and digested with different digestion protocols. A) digestion with P1 nuclease; B) digestion with SVP enzyme; C) digestion with P1 nuclease and SVP enzyme. Final digestion with alkaline phosphatase was included in all protocols. Y-axis represents total ion signal in counts per min (cps). The total ion counts include MS/MS signals for all products that were separated by Hypercarb chromatography: T-Hyd, T-Gly, U-Hyd, U-Gly, C-Imid, 5mC-Hyd, 5mC-Gly, Sp and Gh. Note the different y-axis scale in each sample. 
Figure S3

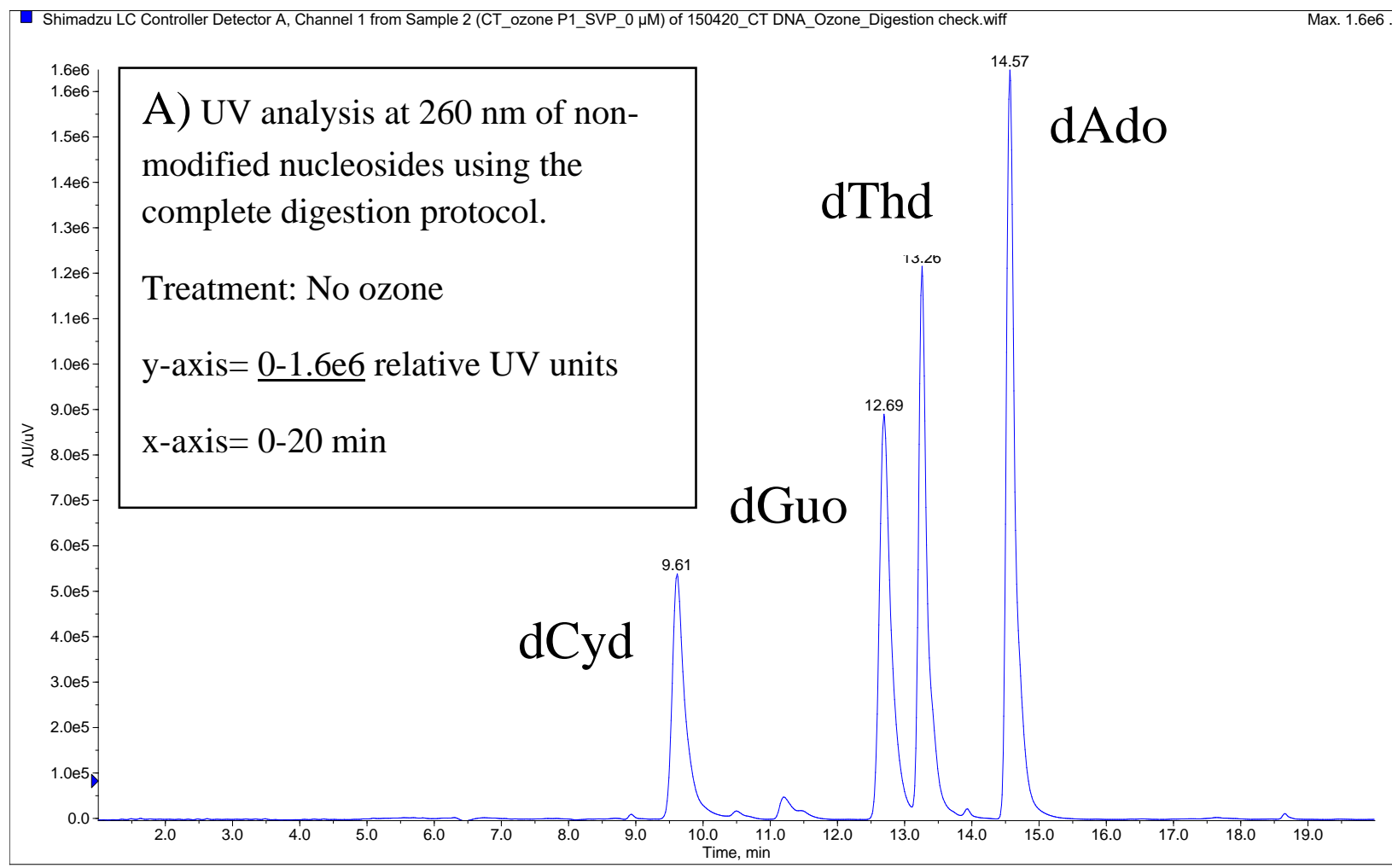

- Shimadzu LC Controller Detector A, Channel 1 from Sample 3 (CT_ozone P1_SVP_300 M) of 150420_CT DNA_Ozone_Digestion check.w...

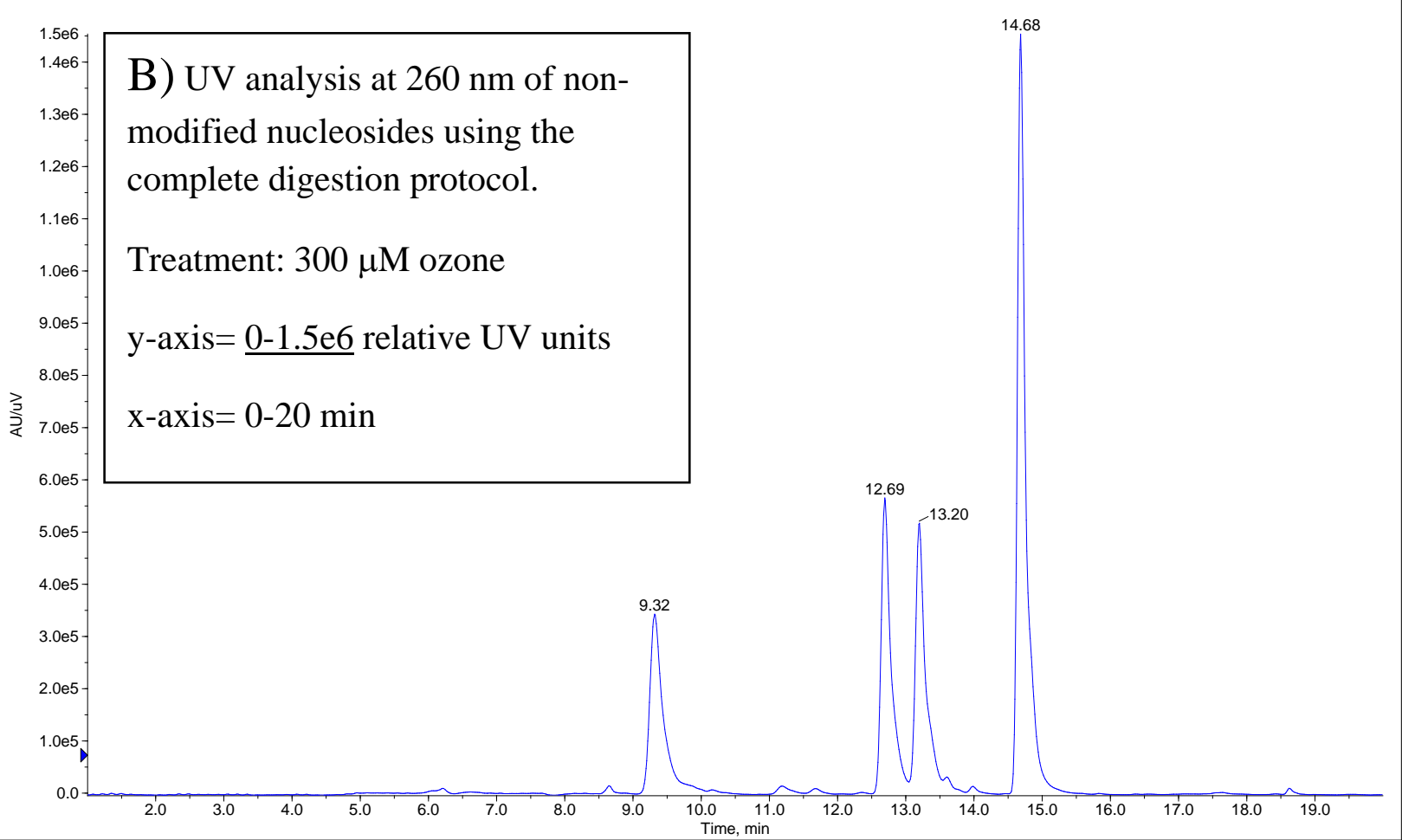


Figure S4

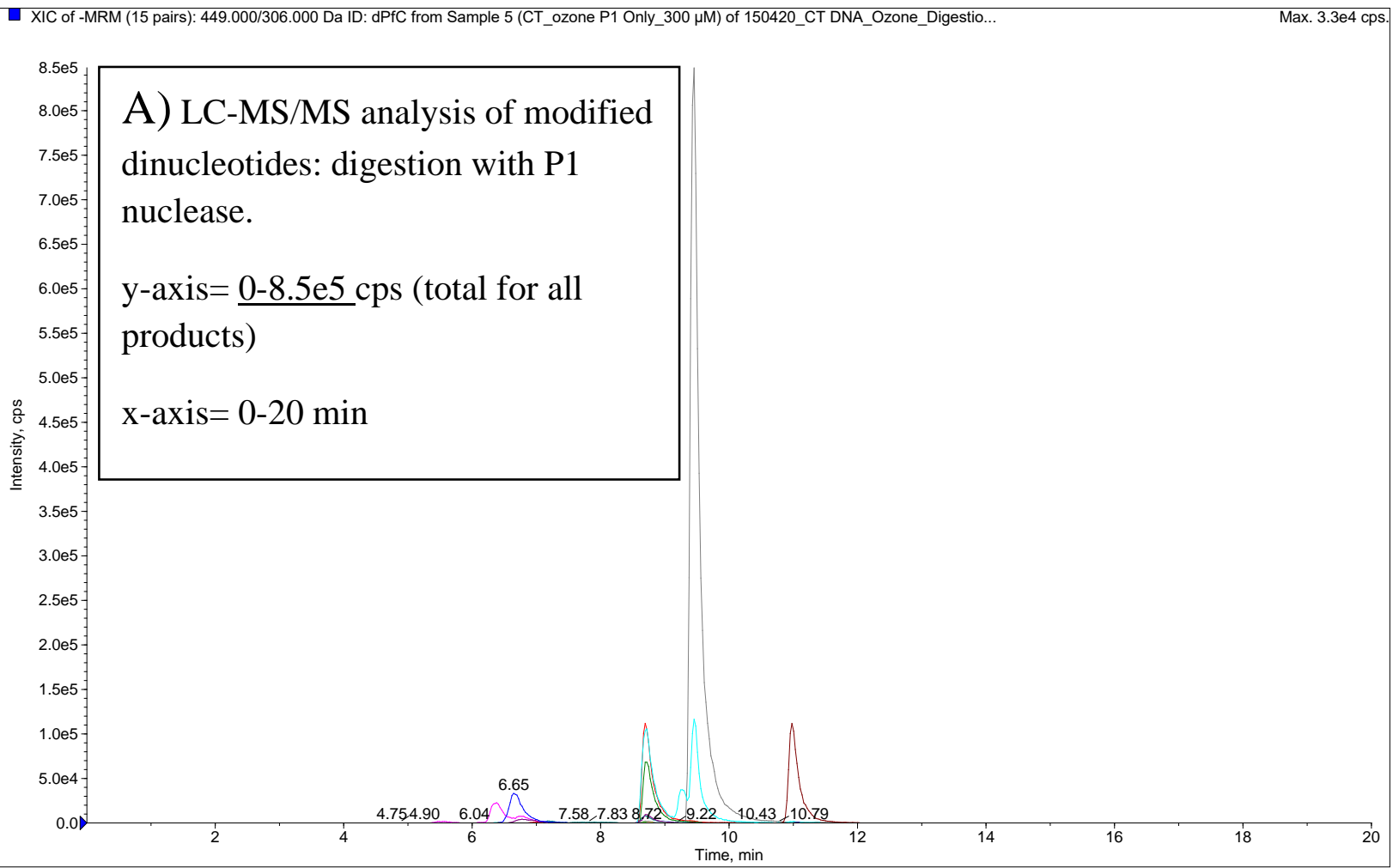

- XIC of -MRM (15 pairs): 449.000/306.000 Da ID: dPfC from Sample 7 (CT_ozone SVP Only_300 $\mu$ M) of 150420_CT DNA_Ozone_Dige...

Max. $2670.0 \mathrm{cps}$

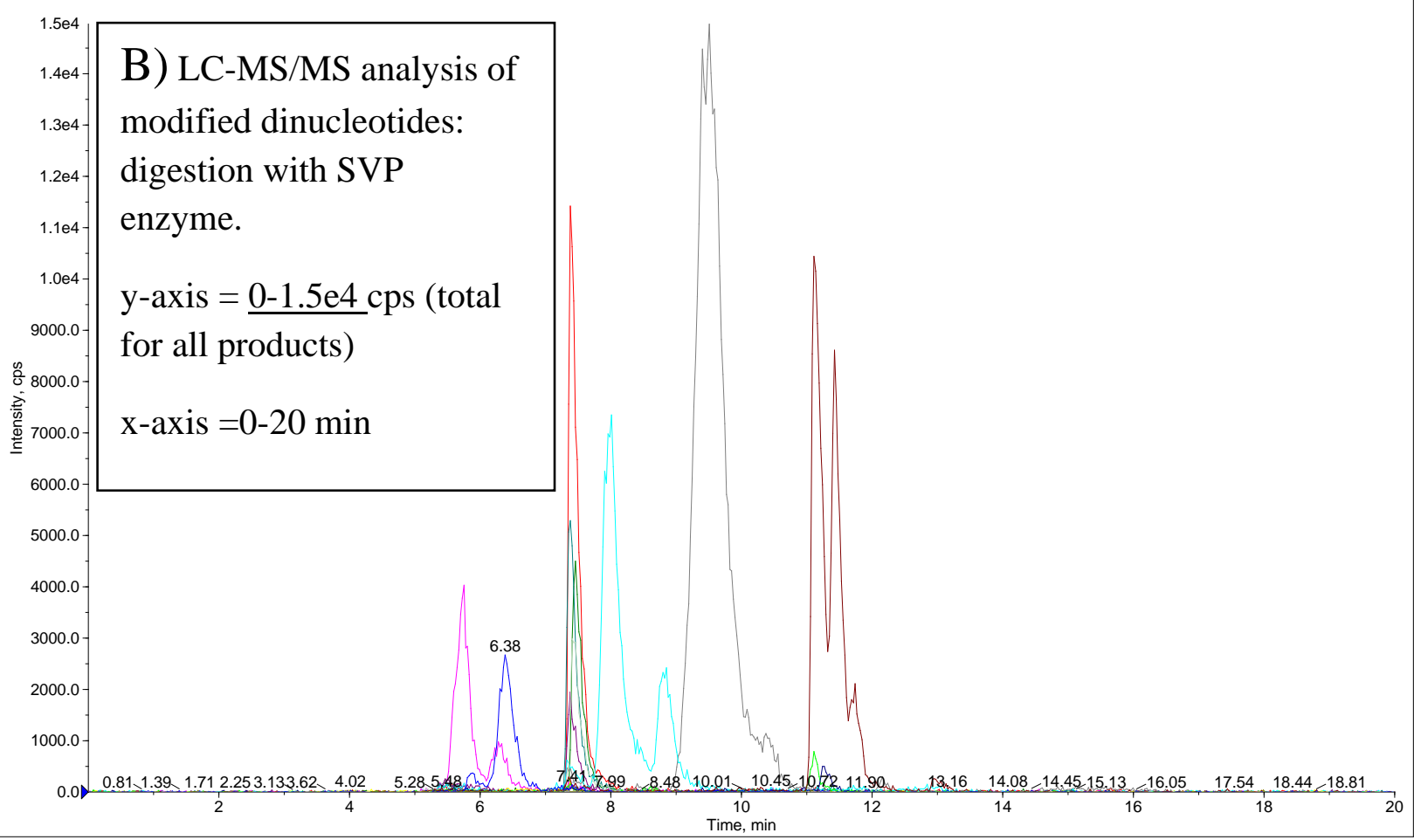


Figure S4 cont.

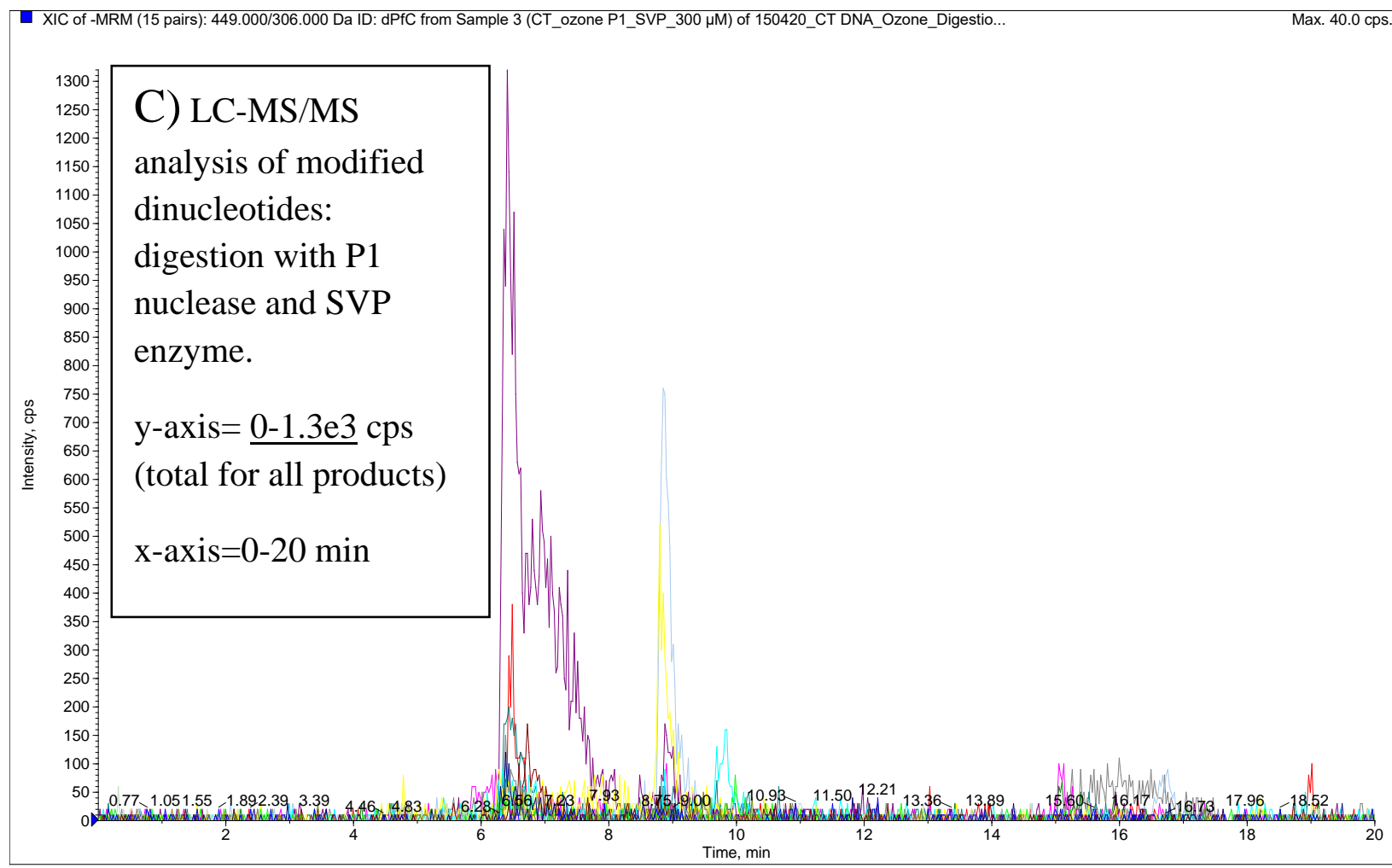

Figure S4. Analysis of modified dinucleotides containing fragments by LC-MS/MS within CTDNA treated with $300 \mu \mathrm{M}$ ozone and digested with different digestion protocols. A) digestion with P1 nuclease; B) digestion with SVP enzyme; C) digestion with P1 nuclease and SVP enzyme. Final digestion with alkaline phosphatase was included in all protocols. Y-axis represents total ion signal in counts per $\min (\mathrm{cps})$. The total ion counts include MS/MS signals for all modified dinucleotide products: $\mathrm{P}^{\mathrm{F}} \mathrm{pA}, \mathrm{P}^{\mathrm{F}} \mathrm{pT}, \mathrm{P}^{\mathrm{F}} \mathrm{pG}, \mathrm{P}^{\mathrm{F}} \mathrm{pC}, \mathrm{P}^{\mathrm{F}} \mathrm{p}$ 8oxoG, $\mathrm{P}^{\mathrm{FU}} \mathrm{pA}, \mathrm{P}^{\mathrm{FU}} \mathrm{pT}$, $\mathrm{P}^{\mathrm{FU}} \mathrm{pG}, \mathrm{P}^{\mathrm{FU}} \mathrm{pC}, \mathrm{P}^{\mathrm{FU}} \mathrm{p}$ 8oxoG, $\mathrm{P}^{\mathrm{U}} \mathrm{pA}, \mathrm{P}^{\mathrm{U}} \mathrm{pT}, \mathrm{P}^{\mathrm{U}} \mathrm{pG}, \mathrm{P}^{\mathrm{U}} \mathrm{pC}, \mathrm{P}^{\mathrm{U}}$ 8 8 oxoG. Note the different y-axis scale in each sample. 
Figure S5. Analysis of T oxidation products by C-18 chromatography.

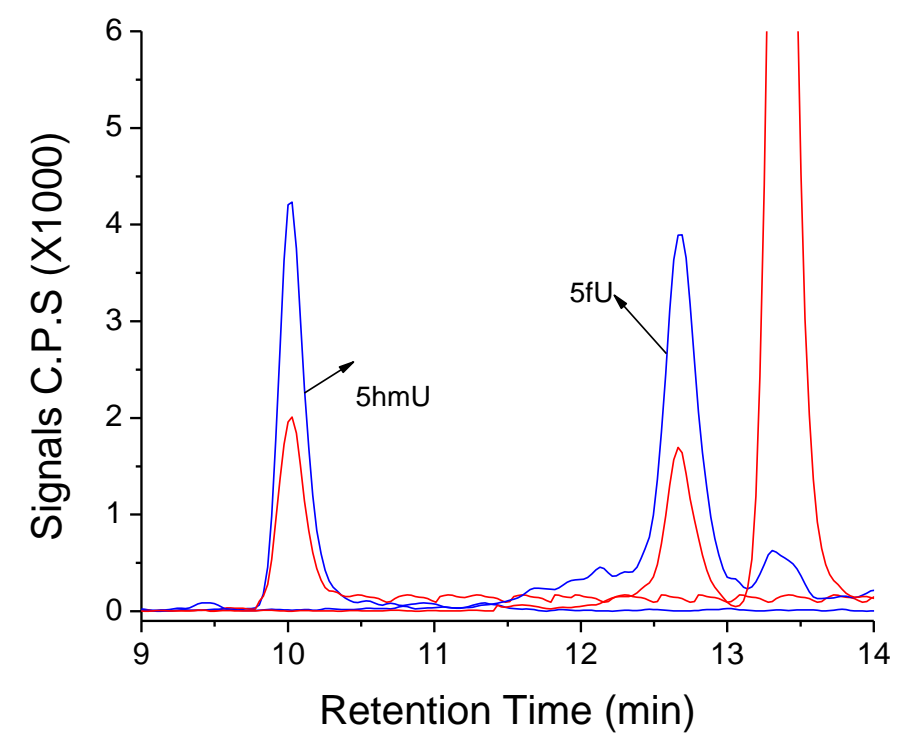

Figure S6. Analysis of T oxidation products by Hypercarb chromatography

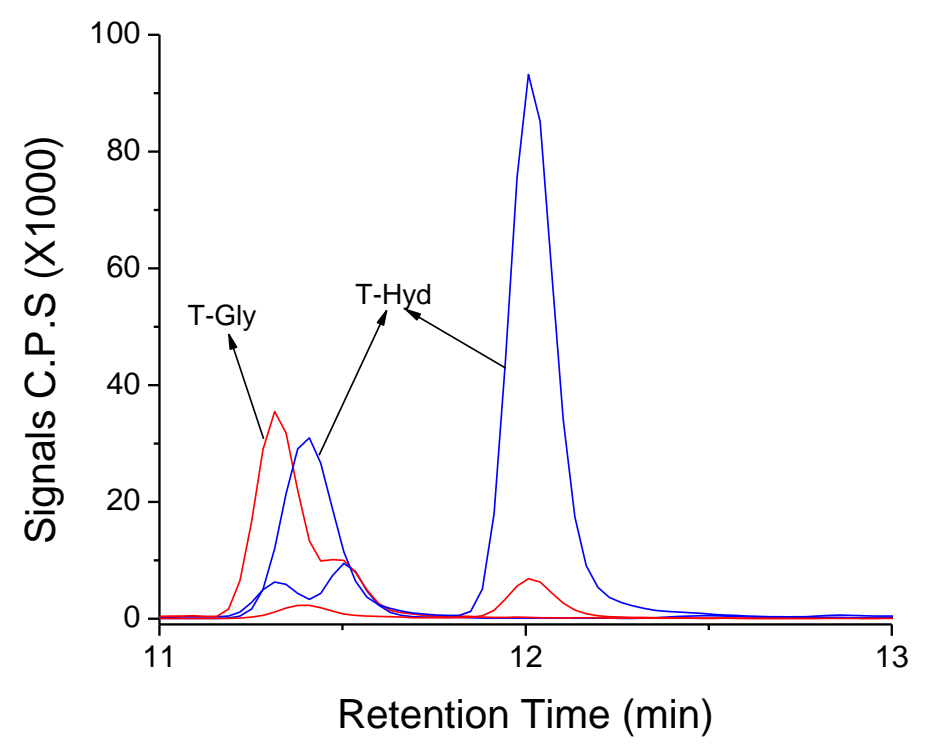

Each product is overlaid with the corresponding labeled standard (red= labeled standard; blue= natural product). Products were detected as the modified 2'-deoxyribonucleoside. 
Figure S7. Analysis of C oxidation products by C-18 chromatography.

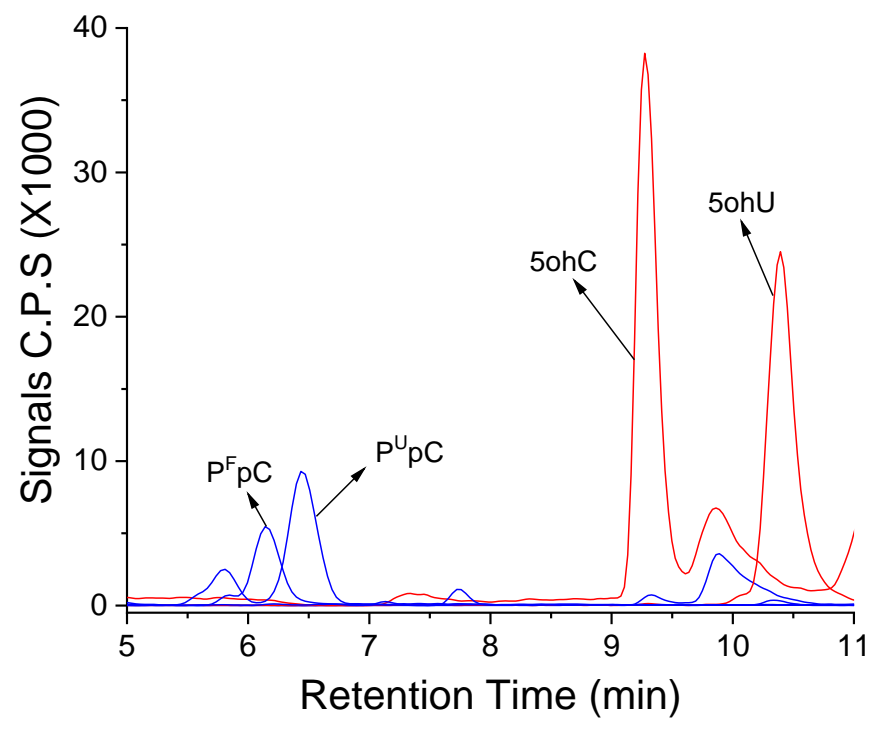

Figure S8. Analysis of C oxidation products by Hypercarb chromatography

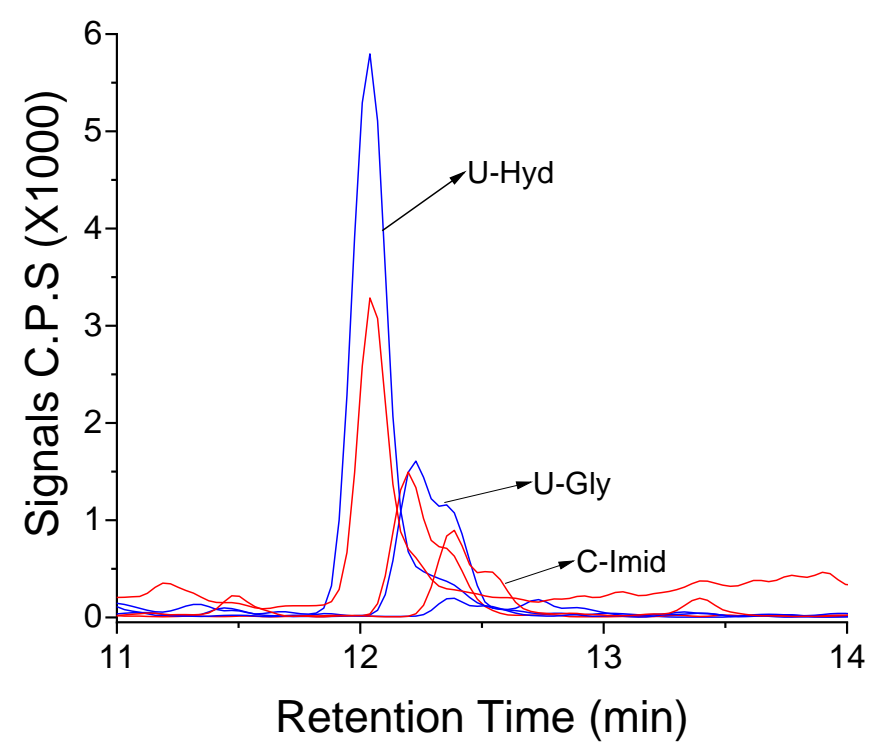

Each product is overlaid with the corresponding labeled standard (red= labeled standard; blue= natural product). Products were detected as the modified 2'-deoxyribonucleoside. 
Figure S9. Analysis of $5 \mathrm{mC}$ oxidation products by $\mathrm{C}-18$ chromatography.

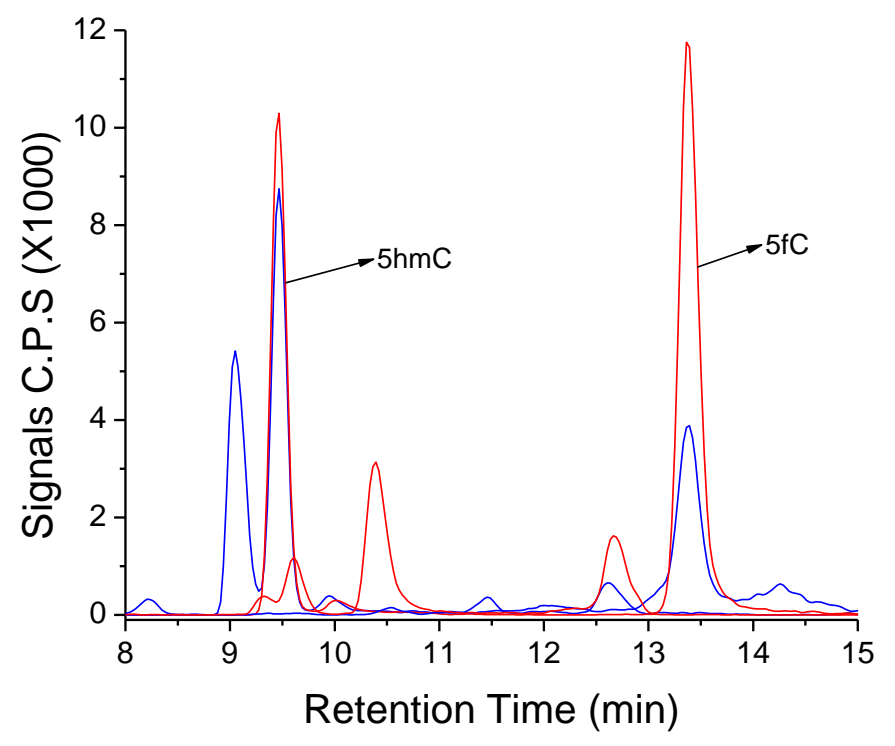

Figure S10. Analysis of $5 \mathrm{mC}$ oxidation products by Hypercarb chromatography

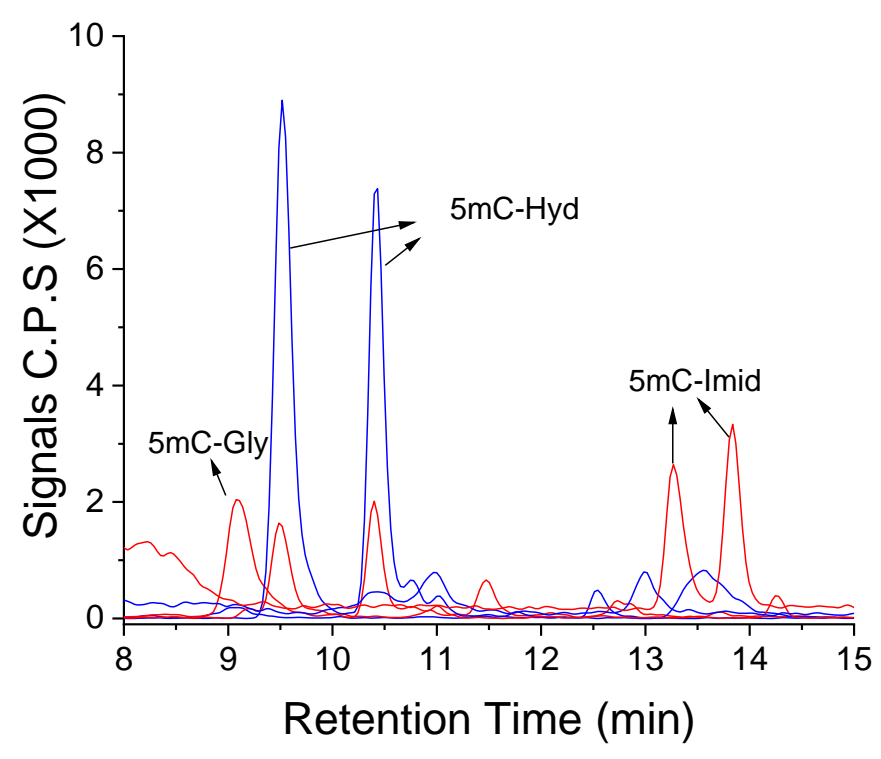

Each product is overlaid with the corresponding labeled standard (red= labeled standard; blue= natural product). Products were detected as the modified 2'-deoxyribonucleoside. 
Figure S11. Analysis of G oxidation products by C-18 chromatography.

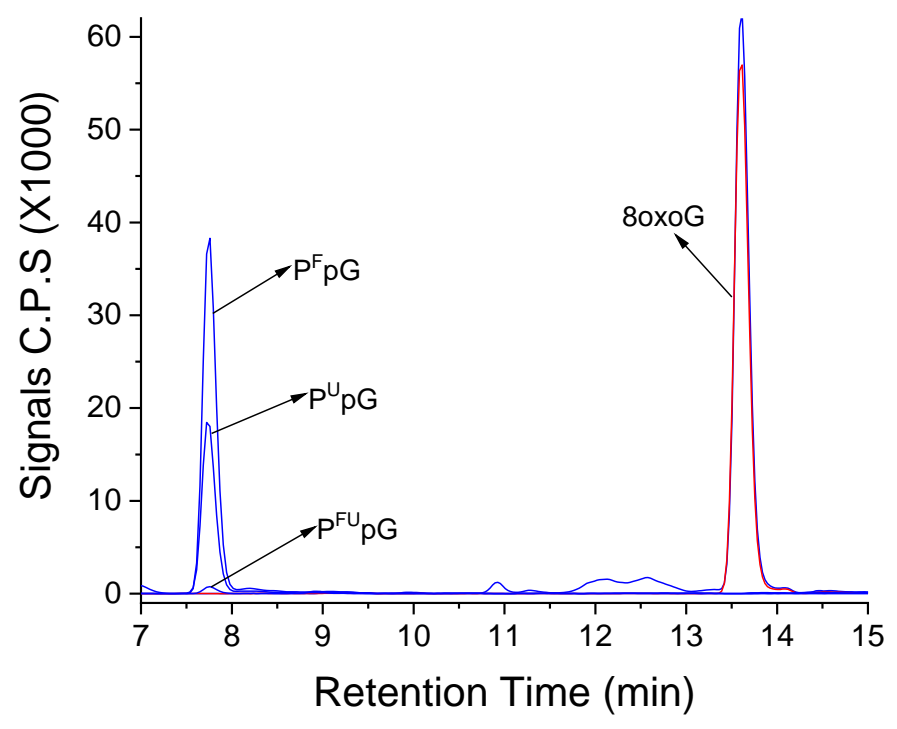

Figure S12. Analysis of G oxidation products by Hypercarb chromatography

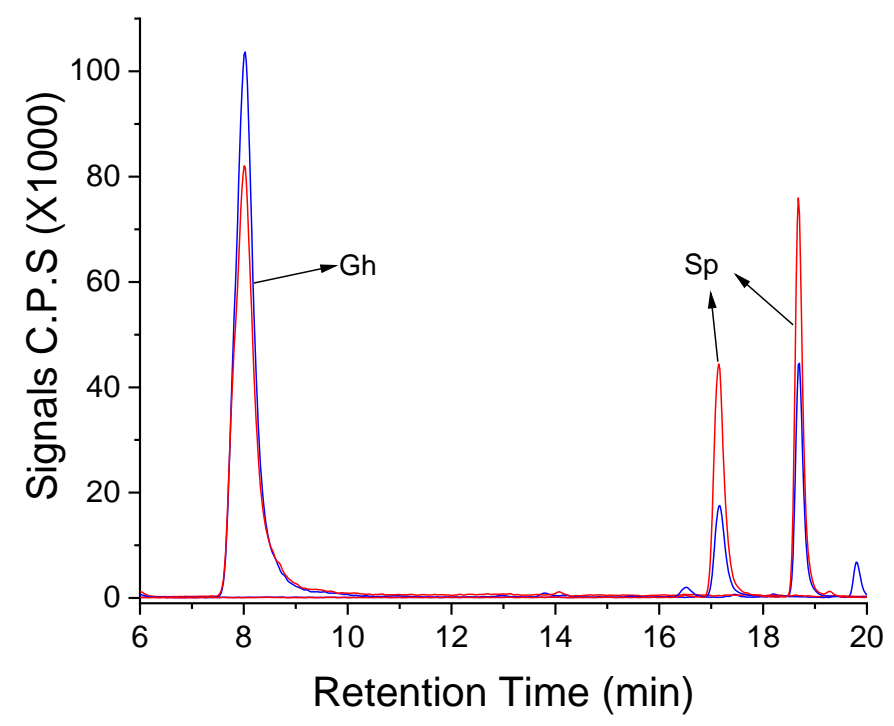

Each product is overlaid with the corresponding labeled standard (red= labeled standard; blue= natural product). Products were detected as the modified 2'-deoxyribonucleoside. 
Figure S13. Formation of C oxidation products

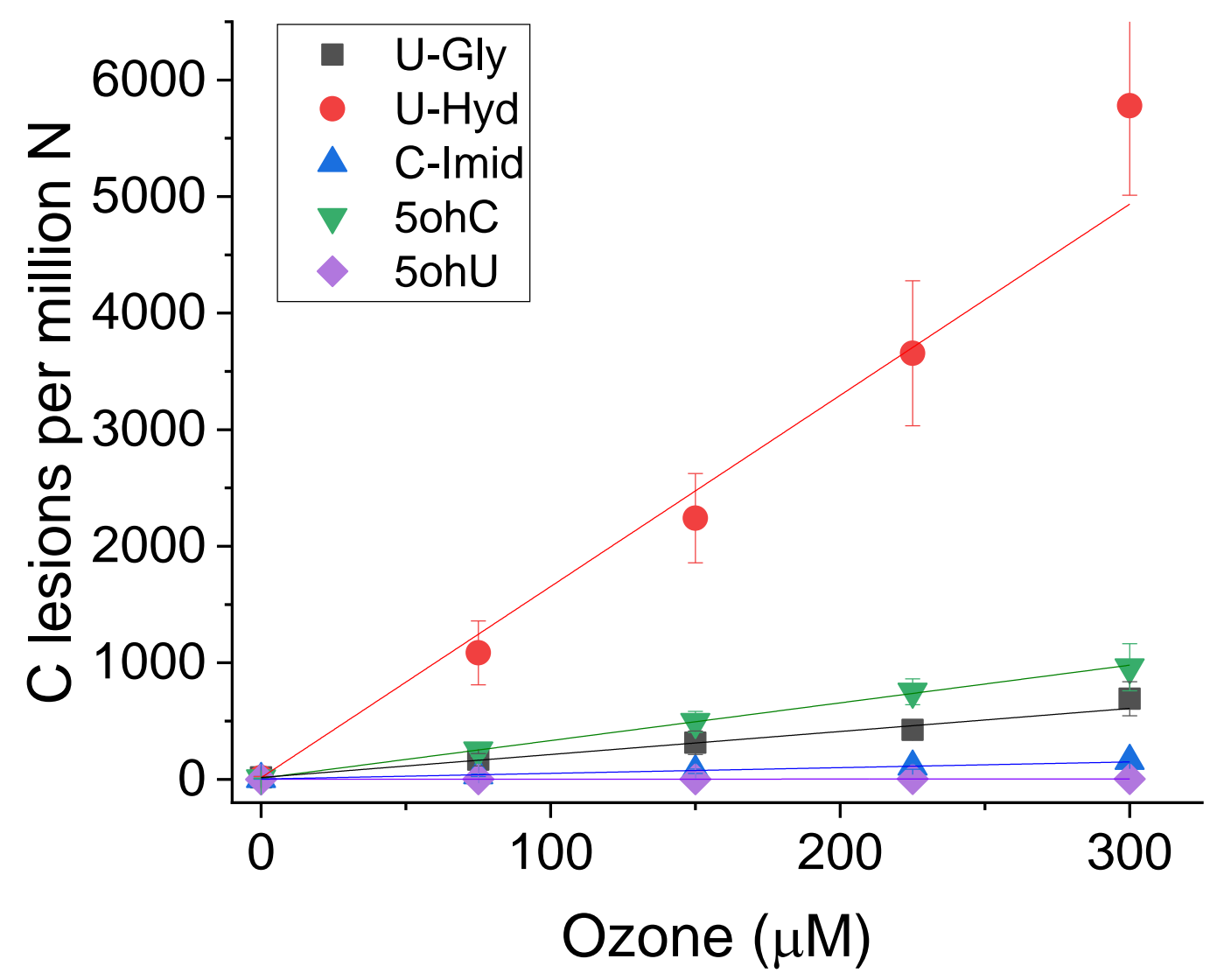

The slopes of the graphs were determined by linear regression analysis with $\mathrm{r}^{2}$ and $\mathrm{P}$ values of statistical significance in parenthesis. The analysis gave the following slope: $\mathrm{U}-\mathrm{Hyd}=16.4 \pm 1.12$ $\left(\mathrm{r}^{2}=0.99 ; \mathrm{P}<0.001\right) ; 5 \mathrm{ohC}=3.24 \pm 0.031\left(\mathrm{r}^{2}=1.00 ; \mathrm{P}<0.001\right) ; \mathrm{U}-\mathrm{Gly}=1.98 \pm 0.11\left(\mathrm{r}^{2}=0.99\right.$; $\mathrm{P}<0.001) ; 5 \mathrm{ohU}=0.009 \pm 0.001\left(\mathrm{r}^{2}=0.96 ; \mathrm{P}=0.004\right) ; \mathrm{C}-\mathrm{Imid}=0.49 \pm 0.021\left(\mathrm{r}^{2}=0.99 ; \mathrm{P}<0.001\right)$ in units of lesions $(\mathrm{C})$ per million nucleosides $(\mathrm{N})$ per $\mu \mathrm{M}$ of ozone. 
Figure S14. Formation of $5 \mathrm{mC}$ oxidation products

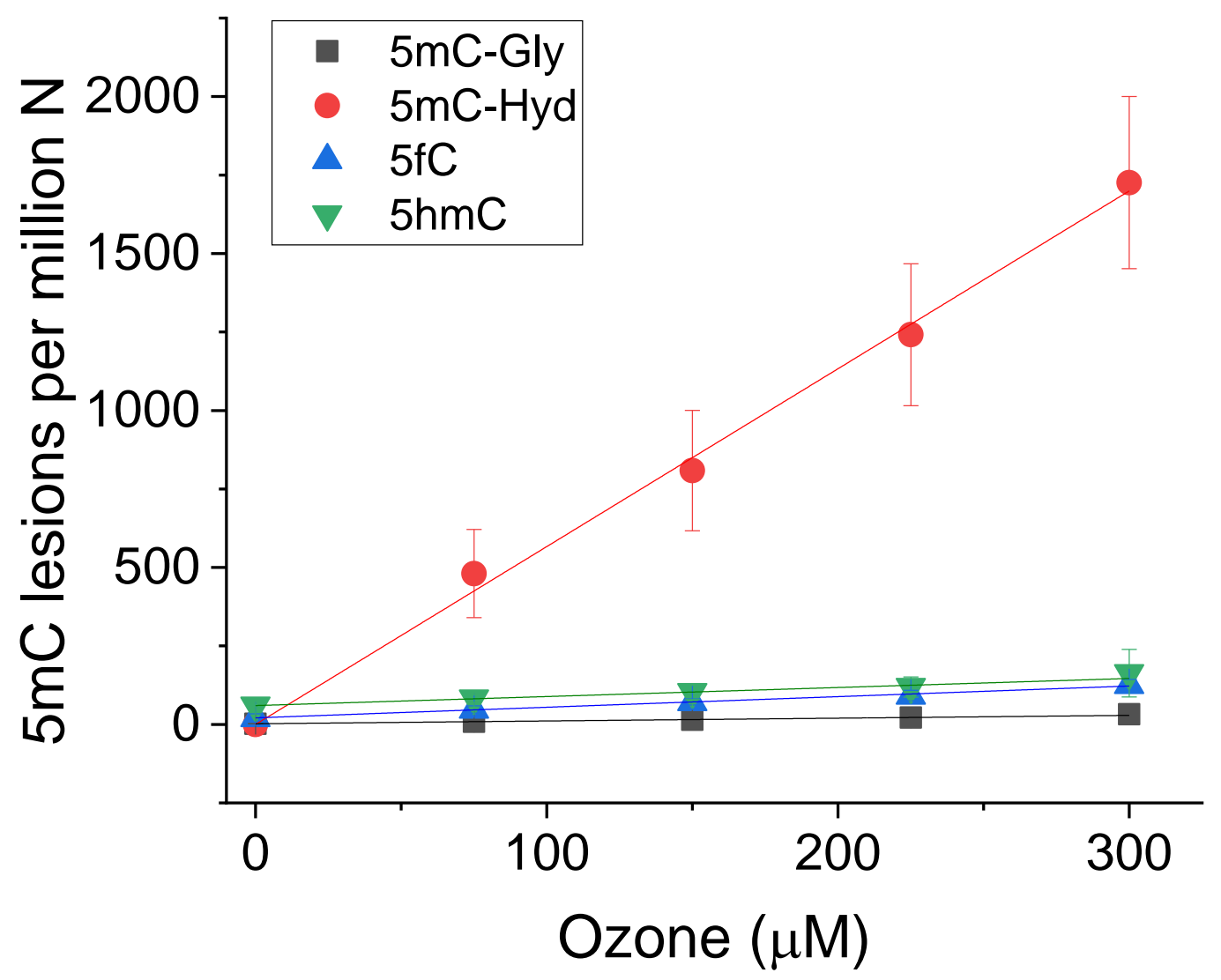

The slopes of the graphs were determined by linear regression analysis with $\mathrm{r}^{2}$ and $\mathrm{P}$ values of statistical significance in parenthesis. The analysis gave the following slope: $5 \mathrm{mC}-\mathrm{Hyd}=5.67 \pm 0.16$ $\left(\mathrm{r}^{2}=1.00 ; \mathrm{P}<0.001\right) ; 5 \mathrm{mC}-\mathrm{Gly}=0.089 \pm 0.004\left(\mathrm{r}^{2}=0.99 ; \mathrm{P}<0.001\right) 5 \mathrm{fC}=0.338 \pm 0.138\left(\mathrm{r}^{2}=1.00\right.$; $\mathrm{P}<0.001) ; 5 \mathrm{hmC}=0.29 \pm 0.014\left(\mathrm{r}^{2}=0.99 ; \mathrm{P}<0.001\right)$ in units of lesions $(5 \mathrm{mC})$ per million nucleosides $(\mathrm{N})$ per $\mu \mathrm{M}$ of ozone. Products were detected as the modified $2^{\prime}$ deoxyribonucleoside. 
Figure S15. Formation of G oxidation products

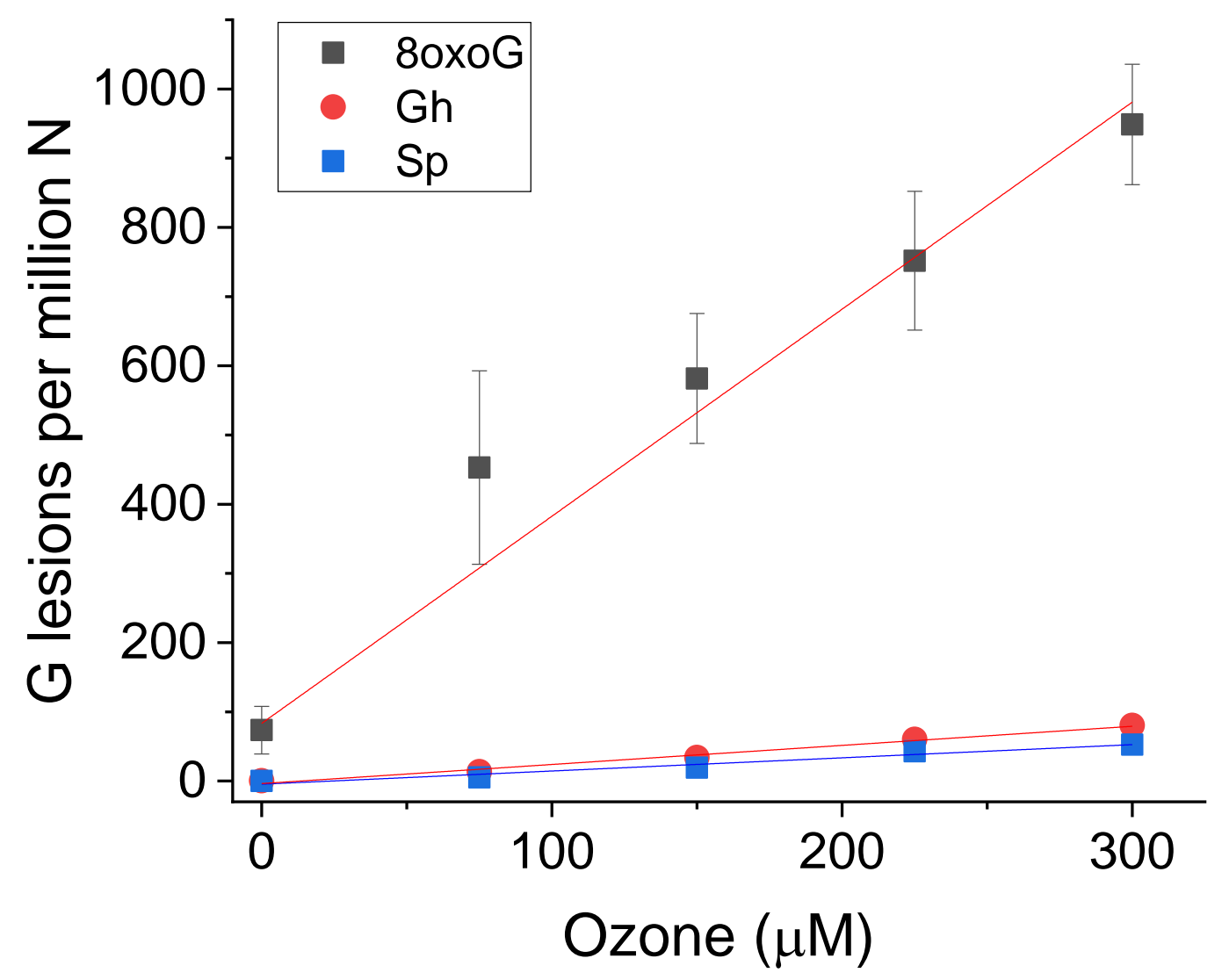

The slopes of the graphs were determined by linear regression analysis with $\mathrm{r}^{2}$ and $\mathrm{P}$ values of statistical significance in parenthesis. The analysis gave the following slope: $8 \mathrm{oxoG}=2.99 \pm 0.19$ $\left(\mathrm{r}^{2}=0.99 ; \mathrm{P}<0.001\right) ; \mathrm{Sp}=0.19 \pm 0.023\left(\mathrm{r}^{2}=0.96 ; \mathrm{P}=0.004\right) ; \mathrm{Gh}=0.28 \pm 0.016\left(\mathrm{r}^{2}=0.99 ; \mathrm{P}<0.001\right)$ in units of lesions per million nucleosides $(\mathrm{N})$ per $\mu \mathrm{M}$ of ozone. Products were detected as the modified 2'-deoxyribonucleoside. 
Figure S16. LC-MS/MS analysis of N-formamide products

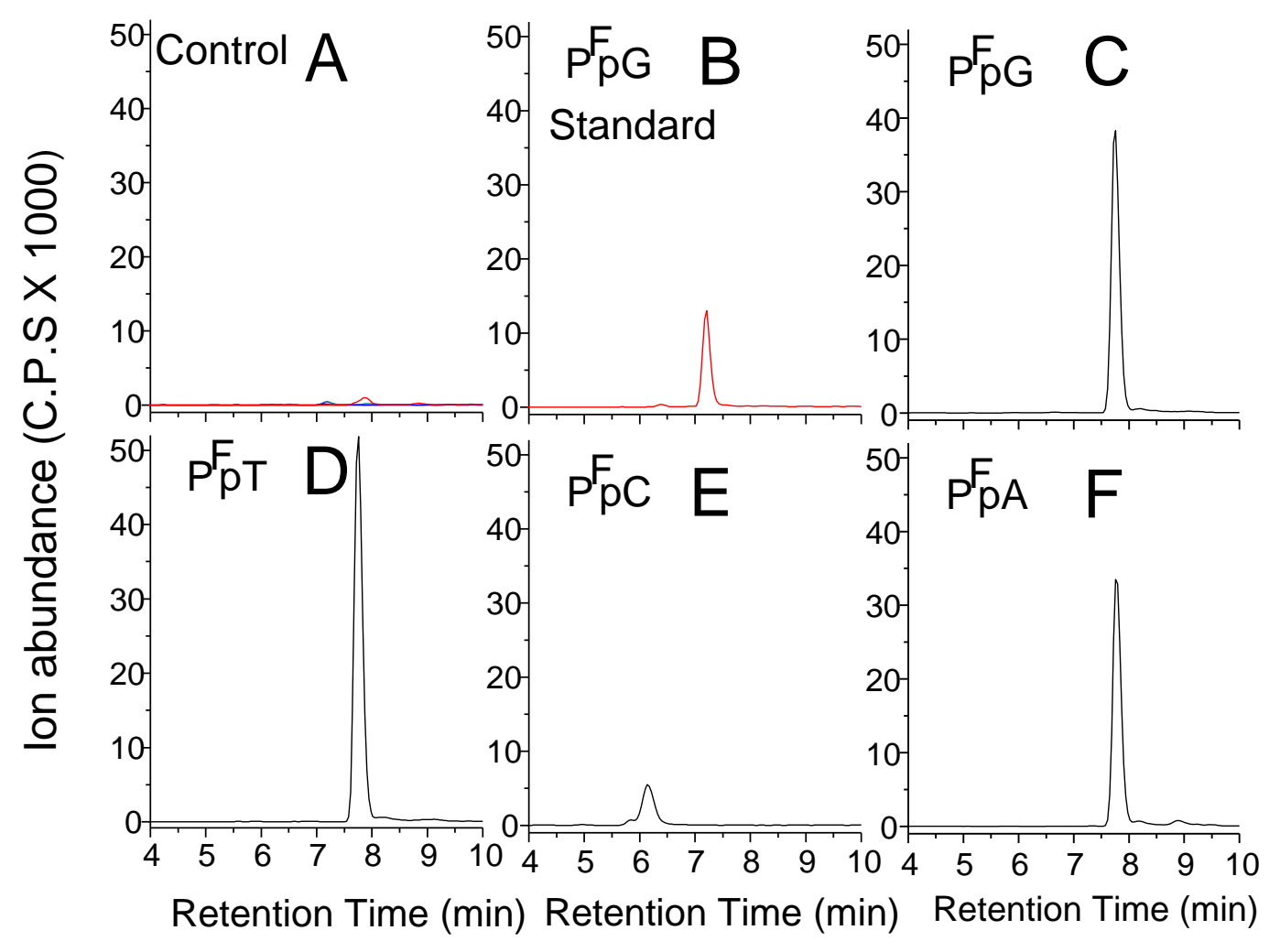

A) Control CT-DNA; (B) $\mathrm{P}^{\mathrm{F}} \mathrm{pG}$ standard spiked in CT-DNA; (C) $\mathrm{P}^{\mathrm{F}} \mathrm{pG}$ in CT-DNA exposed to $48.6 \mu \mathrm{M}$ of ozone; (D) $\mathrm{P}^{\mathrm{F}} \mathrm{pT}$ in CT-DNA exposed to $50 \mu \mathrm{M}$ of ozone; (E) $\mathrm{P}^{\mathrm{F}} \mathrm{pC}$ in CT-DNA exposed to $50 \mu \mathrm{M}$ of ozone; (F) $\mathrm{P}^{\mathrm{F}} \mathrm{pA}$ in CT-DNA exposed to $50 \mu \mathrm{M}$ of ozone. CT-DNA was spiked with $0.42 \mu \mathrm{M}$ of purified $\mathrm{P}^{\mathrm{F}} \mathrm{pG}$ standard spiked before enzymatic digestion. Products were detected as the nucleoside fragment (i.e., $N^{1}$-(formyl)-2'-deoxyribose-(3'-5')-2'-deoxyribonucleoside; $\mathrm{P}^{\mathrm{F}} \mathrm{pN}$ ). 
Figure S17. Formation of dinucleotides containing N-formamide fragments

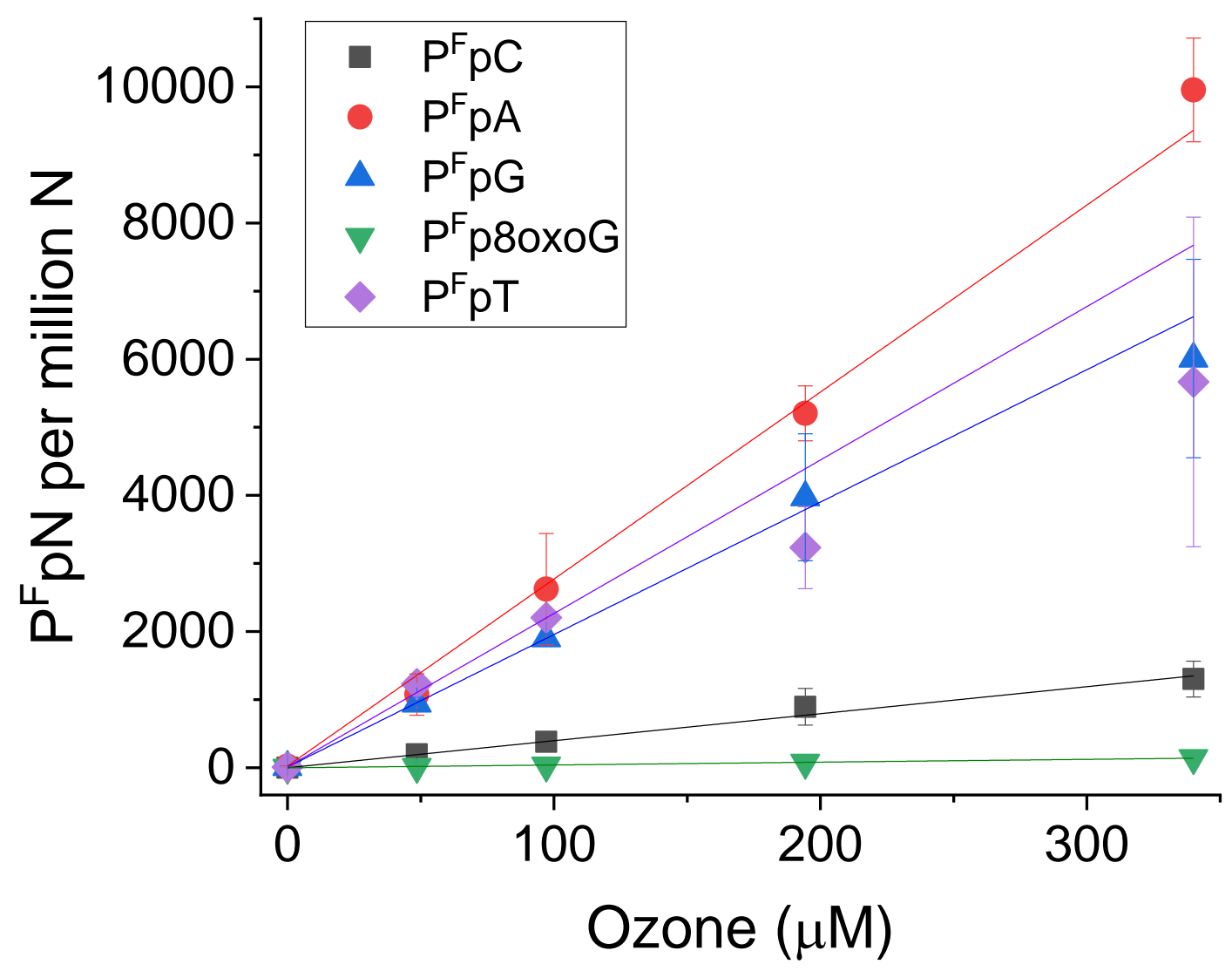

The slopes of the graphs were determined by linear regression analysis with $\mathrm{r}^{2}$ and $\mathrm{P}$ values of statistical significance in parenthesis. The analysis gave the following slope: $\mathrm{P}^{\mathrm{F}} \mathrm{pC}=4.0 \pm 0.3$ $\left(\mathrm{r}^{2}=1.00 ; \mathrm{P}<0.001\right) ; \mathrm{P}^{\mathrm{F}} \mathrm{pA}=27.5 \pm 1.5\left(\mathrm{r}^{2}=1.00 ; \mathrm{P}<0.001\right) ; \mathrm{P}^{\mathrm{F}} \mathrm{pG}=19.4 \pm 0.5\left(\mathrm{r}^{2}=1.00 ; \mathrm{P}<0.001\right)$; $\mathrm{P}^{\mathrm{F}} \mathrm{p} 80 x \mathrm{og}=0.4 \pm 0.0\left(\mathrm{r}^{2}=1.00 ; \mathrm{P}<0.001\right) ; \mathrm{P}^{\mathrm{F}} \mathrm{pT}=22.5 \pm 0.7\left(\mathrm{r}^{2}=1.00 ; \mathrm{P}<0.001\right)$ in units of lesions $\left(\mathrm{P}^{\mathrm{F}} \mathrm{N}\right)$ per million nucleosides $(\mathrm{N})$ per $\mu \mathrm{M}$ of ozone. 
Figure S18. Formation of dinucleotides containing N-urea fragments

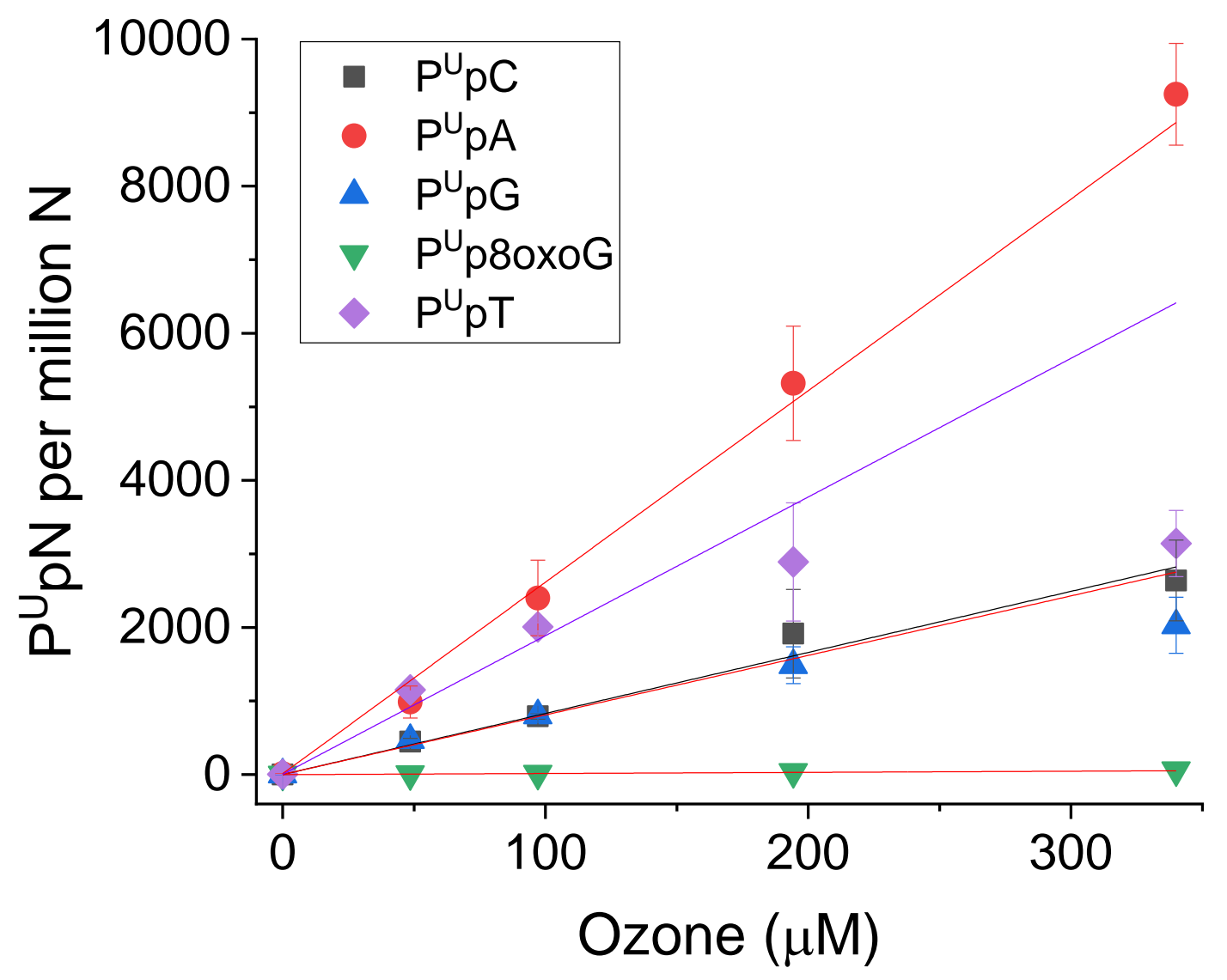

The slopes of the graphs were determined by linear regression analysis with $\mathrm{r}^{2}$ and $\mathrm{P}$ values of statistical significance in parenthesis. The analysis gave the following slope: $\mathrm{P}^{\mathrm{U}} \mathrm{pC}=8.30 \pm 0.24$ $\left(\mathrm{r}^{2}=1.00 ; \mathrm{P}<0.001\right) ; \mathrm{P}^{\mathrm{U}} \mathrm{pA}=26.0 \pm 1.4\left(\mathrm{r}^{2}=0.99 ; \mathrm{P}<0.001\right) ; \mathrm{P}^{\mathrm{U}} \mathrm{pG}=8.1 \pm 0.4\left(\mathrm{r}^{2}=0.99 ; \mathrm{P}<0.001\right) ;$ $\mathrm{P}^{\mathrm{U}}$ p8oxoG= $0.2 \pm 0.0\left(\mathrm{r}^{2}=0.95 ; \mathrm{P}=0.004\right) ; \mathrm{P}^{\mathrm{U}} \mathrm{pT}=18.9 \pm 2.7\left(\mathrm{r}^{2}=0.94 ; \mathrm{P}=0.006\right)$ in units of lesions $\left(\mathrm{P}^{\mathrm{U}} \mathrm{pN}\right.$ per million nucleosides $(\mathrm{N})$ per $\mu \mathrm{M}$ of ozone. 
Figure S19. Formation of dinucleotides containing N,N-formylurea fragments

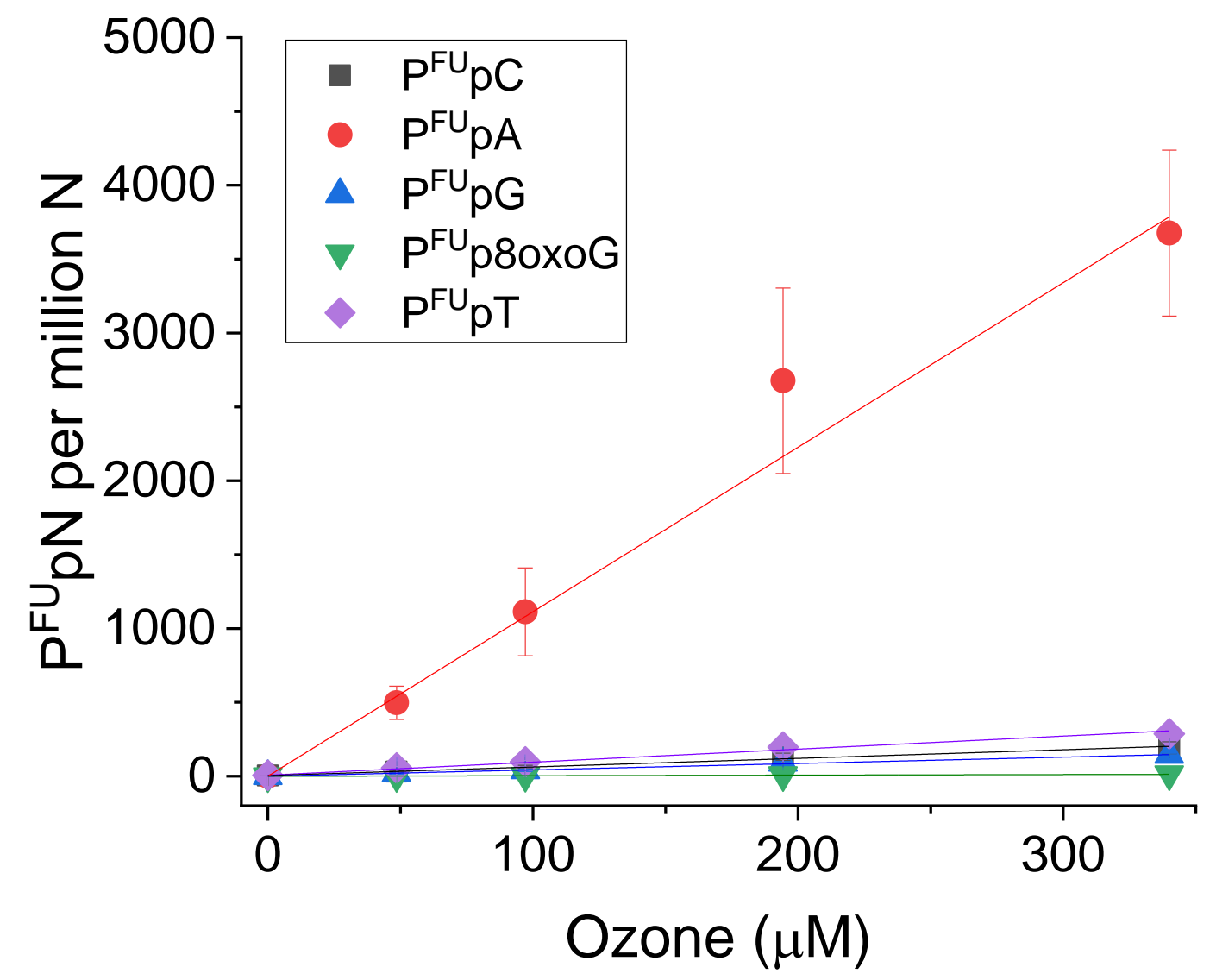

The slopes of the graphs were determined by linear regression analysis with $\mathrm{r}^{2}$ and $\mathrm{P}$ values of statistical significance in parenthesis. The analysis gave the following slope: $\mathrm{P}^{\mathrm{FU}} \mathrm{pC}=0.6 \pm 0.0$ $\left(\mathrm{r}^{2}=1.00 ; \mathrm{P}<0.001\right) ; \mathrm{P}^{\mathrm{FU}} \mathrm{pA}=11.1 \pm 0.6\left(\mathrm{r}^{2}=0.99 ; \mathrm{P}<0.001\right) ; \mathrm{P}^{\mathrm{FU}} \mathrm{pG}=0.4 \pm 0.0\left(\mathrm{r}^{2}=1.00 ; \mathrm{P}<0.001\right) ;$ $\mathrm{dP}^{\mathrm{FU}} \mathrm{p} 8$ oxoG= $0.04 \pm 0.00\left(\mathrm{r}^{2}=0.98 ; \mathrm{P}<0.001\right) ; \mathrm{P}^{\mathrm{FU}} \mathrm{pT}=0.9 \pm 0.0\left(\mathrm{r}^{2}=0.99 ; \mathrm{P}<0.001\right)$ in units of lesions $\mathrm{P}^{\mathrm{FU}} \mathrm{pN}$ per million nucleosides $(\mathrm{N})$ per $\mu \mathrm{M}$ of ozone. 
Scheme S1. Rearrangement of 5-hydroxyhydantoin products.

Base isomerization: e.g., $5 \mathrm{R}$ to $5 \mathrm{~S}$ (possible for the nucleoside and DNA)<smiles>CC(=O)C(=O)NC(=O)NC1CC(O)(CO)OC1CO</smiles>

Sugar isomerization: $\beta$ to $\alpha$ (possible for the nucleoside and DNA)<smiles></smiles>

Sugar isomerization: furanose to pyranose (only possible for the nucleoside)

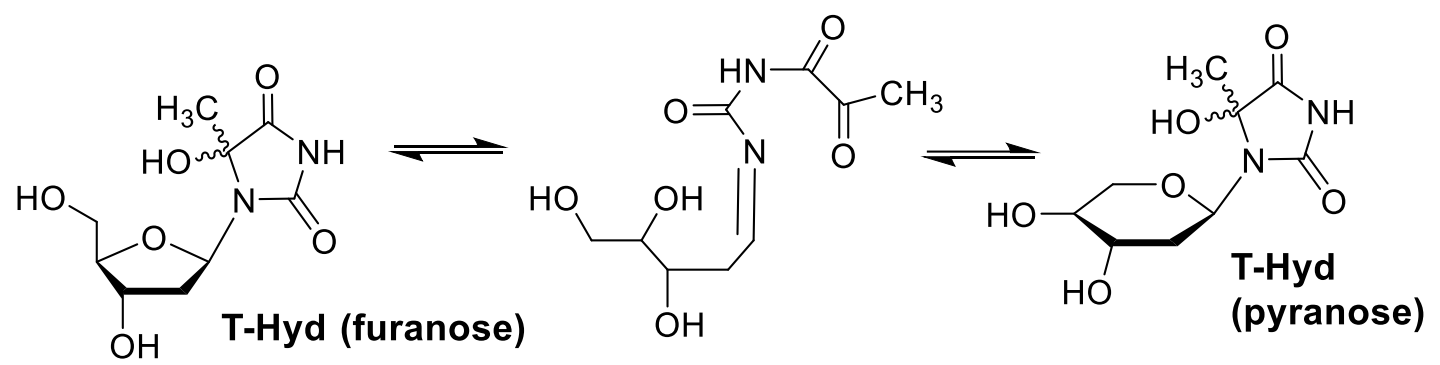

Scheme |S2. Decomposition of 5,6-dihydroxy-5,6-dihydrocytosine: deamination to 5,6dihydroxy-5,6-dihydrouracil (U-Gly) and dehydration to 5-hydroxycytosine (5ohC).<smiles>Cn1ccc(N)nc1=O</smiles>

\section{Cytosine (C)}<smiles>CN1C(=O)N=C(N)C(O)C1(O)O</smiles>

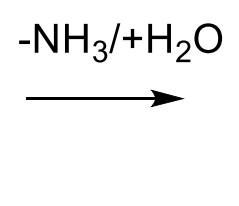<smiles>C=CCC</smiles><smiles>CN1C(=O)NC(=O)C(O)C1(O)O</smiles><smiles>Cn1cc(O)c(N)nc1=O</smiles>

5ohC 